\title{
СМЕРТНОСТЬ В МОСКВЕ И ДРУГИХ МЕГАПОЛИСАХ МИРА: СХОДСТВА И РАЗЛИЧИЯ
}

\author{
ЕВГЕНИЙ АНДРЕЕВ, ЕКАТЕРИНА КВАША, ТАТЬЯНА ХАРЬКОВА
}

\begin{abstract}
Статья посвящена сравнению смертности по причинам смерти в Москве и в других мегаполисах мира в период после 1990 г. Выбор мегаполисов определялся доступностью подробных данных о смертности в рассматриваемый период. Объектами сравнения стали Берлин, Гонконг, Лондон, ЛосАнджелес, Нью-Йорк, Санкт-Петербург, Сингапур, Токио. Рассмотрена смертность от основньх групп причин смерти, включая болезни системы кровообращения, новообразования, внешние причины, болезни органов дыхания и пищеварения, инфекции и некоторые другие. Анализ основан на стандартизованных коэффициентах смертности по причинам смерти.

Уровень смертности в Москве существенно ниже, чем в большинстве регионов России, но попрежнему существенно выще, чем в зарубежных мегаполисах. За счет отставания в начале рассматриваемого периода уровень смертности в Москве остается выше, чем во всех зарубежных мегаполисах в 2000 г. Наиболее сильно Москва проигрывает по уровню смертности от болезней системы кровообращения и внешних причин. Успехи Москвы в снижении смертности в 2000-2014 г2. внушают некоторый оптимизм, однако трудно предугадать, как будут развиваться события в условиях ухудшающейся экономической ситуации.
\end{abstract}

Ключевые слова: Москва, смертность, причины смерти, мегаполисы, болезни системы кровообращения, внешние причины, новообразования.

На фоне общероссийских тенденций ситуация со смертностью в Москве в настоящее время выглядит весьма благоприятной. В начале 1990-х годов стандартизованный коэффициент смертности $(\mathrm{CKC})^{1}$ и мужчин, и женщин в Москве практически не отличался от показателей по городским поселениям Центрального федерального округа (ЦФО), за исключением Москвы, и по Санкт-Петербургу (рисунок 1). В среднем за 1990-1994 гг. СКС в Москве был ниже у мужчин лишь на 3-4\%, а у женщин даже выше почти на 3\% по сравнению с другими городами ЦФО, но ниже, чем в Санкт-Петербурге, на 3,5\%. В течение последующих четырех лет вплоть до 1998 г. динамика и уровень смертности в двух столицах демонстрировали почти полное совпадение, но затем их пути разошлись. В Москве продолжилось снижение смертности и у мужчин, и у женщин, а в Санкт-Петербурге и в городах ЦФО, за исключением Москвы, так же, как и в стране в целом, отмечался рост смертности, а снижение началось только с 2004 г.

\footnotetext{
ЕВГЕНИЙ МИХАЙЛОВИЧ АНДРЕЕВ, РОССИЙСКАЯ ЭКОНОМИЧЕСКАЯ ШКОЛА, РОССИЯ.

ЕКАТЕРИНА АЛЕКСАНДРОВНА КВАША, НАЦИОНАЛЬНЫЙ ИССЛЕДОВАТЕЛЬСКИЙ УНИВЕРСИТЕТ «ВЫСШАЯ ШКОЛА ЭКОНОМИКИ», РОССИЯ.

ТАТЬЯНА ЛЕОНИДОВНА ХАРЬКОВА (tkharkova@hse.ru), НАЦИОНАЛЬНЫЙ ИССЛЕДОВАТЕЛЬСКИЙ УНИВЕРСИТЕТ «ВЫСШАЯ ШКОЛА ЭКОНОМИКИ», РОССИЯ.
}

СТАТЬЯ ПОДГОТОВЛЕНА ПО РЕЗУЛЬТАТАМ ИССЛЕДОВАТЕЛЬСКОГО ПРОЕКТА «ТЕНДЕНЦИИ ДЕМОГРАФИЧЕСКОГО РАЗВИТИЯ РОССИИ В 2005-2015 ГГ. В КОНТЕКСТЕ ДОЛГОВРЕМЕННЫХ ДЕМОГРАФИЧЕСКИХ ТРЕНДОВ», ВЫПОЛНЕННОГО В РАМКАХ ПРОГРАММЫ ФУНДАМЕНТАЛЬНЫХ ИССЛЕДОВАНИЙ НИУ ВШЭ В 2016 Г.

СТАТЬЯ ПОСТУПИЛА В РЕДАКЦИЮ В ИЮЛЕ 2016 Г.

\footnotetext{
1 Здесь и далее при расчете стандартизованных показателей в качестве стандарта используется Европейское стандартное население 1976 г. [Waterhouse et all. 1976]
} 
В результате отрыв Москвы от других городов ЦФО и от Санкт-Петербурга стал более значительным. Так, если в 2000 г. СКС в Москве был ниже, чем в Санкт-Петербурге, у мужчин на $18 \%$ и у женщин на $13 \%$, а по сравнению с городами ЦФО без Москвы соответственно на 29 и 18\%, то в 2014 г. разрыв увеличился соответственно до 21 и 45\% у мужчин и 15 и $30 \%$ у женщин.

По динамике СКС для женщин города ЦФО, за исключением Москвы, неотличимы от России в целом, у мужчин смертность по стране в целом немного ниже, чем по ЦФО. К концу периода СКС в Москве был ниже общероссийского для мужчин в 1,7 раза, а для женщин в 1,4 раза. Если не брать в расчет республики Северного Кавказа, где данные статистики смертности до сих пор вызывают сомнения, то обнаружится, что в Москве со второй половины 1990-х годов отмечаются самые низкие среди регионов России СКС (с 1997 г. у мужчин и с 1999 г. у женщин).

Почти весь период после 1990 г. динамика смертности в Москве была гораздо более благоприятной, чем в большинстве регионов России. Однако в главном она формировалась теми же факторами, что и общероссийская динамика. После существенного падения уровня смертности в стране в годы антиалкогольной кампании уже в конце 1980-х годов начался его медленный рост. Рост ускорился в начале 1990-х, когда кампания была полностью прекращена и произошло значительное падение продолжительности жизни, минимум которой был зафиксирован в 1994 г. К 1998 г. уровень смертности в стране снизился, но остался существенно выше, чем 1990 г., затем на фоне финансового кризиса 1998 г. произошел новый рост, продолжавшийся до 2003 г. Рост смертности после 1998 г. связывают с финансовым кризисом, но общепринятого объяснения причин ее снижения между 1994 и 1998 г. и ее роста между 1998 и 2003 г. не существует [Вишневский 2006: 293 323; Школьников и др. 2014]. После 2003 г. в стране началось устойчивое снижение смертности, которое продолжается до настоящего времени, сильно замедлившись в условиях нового экономического кризиса [Андреев и др. 2015; Школьников и др. 2014; Андреев, Кваша, Харькова 2013].

Главное отличие динамики смертности в Москве от общероссийских тенденций (рисунок 1) в том, что после пика 1994 г. ухудшение ситуации в смертности было весьма умеренным, а начиная с 2001 г., т.е. на 3 года раньше, чем в стране, началось устойчивое снижение.

Как бы высоко мы не оценивали успехи Москвы при внутрироссийских сравнениях, на фоне европейских стран - «старых» членов $\mathrm{EC}^{2}$ (EC-15) уровень смертности в Москве остается высоким, хотя некоторое сближение с ними, особенно у женщин, в течение последнего двадцатилетия и отмечается. Если в 1995 г. СКС в Москве был выше аналогичного показателя в среднем по странам ЕС-15 у мужчин в 2,2 раза и у женщин в 1,9 раза, то в 2013 г. - соответственно в 1,5 и 1,1 раза. Иная картина отмечается при сравнении Москвы со средними показателями для стран - «новых» членов ЕС ${ }^{3}$. Вплоть до 2010 г. СКС

\footnotetext{
${ }^{2}$ Страны, вступившие в ЕС до мая 2004 г.: Австрия, Бельгия, Великобритания, Германия, Греция, Дания, Италия, Ирландия, Испания, Люксембург, Нидерланды, Португалия, Финляндия, Франция, Швеция.

${ }^{3}$ Страны, вступившие в ЕС после мая 2004 г.: Болгария, Венгрия, Кипр, Латвия, Литва, Мальта, Польша, Румыния, Словакия, Словения, Чехия, Эстония.
} 
в Москве были выше, чем в 12 странах - новых членах ЕС, особенно в 1993-1995 и 20002003 гг., когда превышение составляло соответственно у мужчин 42-53 и 21-23\%, а у женщин 20-25 и 16-17\%. Однако, начиная с 2011 г., смертность в Москве и у мужчин, и у женщин стала несколько ниже, чем в 12 новых странах ЕС.

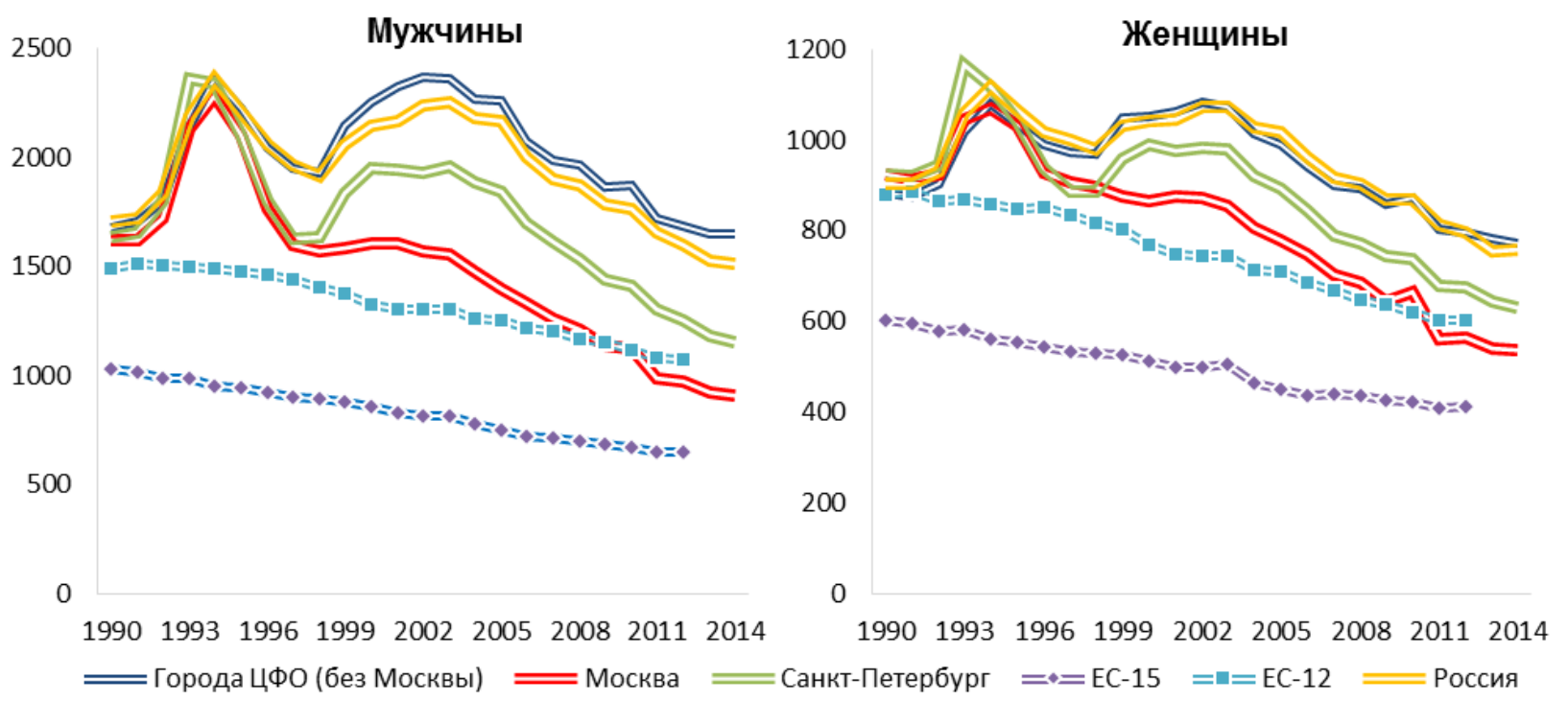

Рисунок 1. Стандартизованный коэффициент смертности от всех причин в Москве, городском населении ЦФО без Москвы, Санкт-Петербурге и ЕС-15, 1990-2014, на 100000

Москва не только столица России, но и один из крупнейших мегаполисов мира [UN 2015]. В 2014 г. Москва занимала 21-е место среди крупнейших городских агломераций мира, поэтому вполне логично сравнивать уровень смертности в Москве со смертностью в других крупнейших мегаполисах.

\section{ДАННЫЕ}

Первостепенное внимание при отборе мегаполисов уделялось их размеру по численности населения и наличию качественных статистико-демографических данных. В частности, выбор сравниваемых мегаполисов был обусловлен наличием в открытых источниках стандартизированных коэффициентов смертности или распределения чисел умерших по возрасту, полу и причинам смерти. В результате были отобраны мегаполисы, расположенные в разных частях мира, а также второй после Москвы российский мегаполис - Санкт-Петербург (таблица 1).

Мы будем сравнивать данные за 4 года: 1990 г. (или первый следующий за ним год, за который имеются данные), 2000, 2010 и 2013 г. (или последний год, за который имеются данные).

Сравнительный анализ проводится как по крупным классам причин смерти, так и по отдельным важнейшим группам причин внутри классов, определяющим основные изменения общей смертности. 
К сожалению, не по всем выбранным городам (мегаполисам) имеются данные по полному перечню рассматриваемых нами причин смерти. Поэтому по нескольким городам в анализе участвуют только некоторые причины.

Таблица 1. Мегаполисы, отобранные для сравнения с Москвой

\begin{tabular}{|c|c|c|c|c|}
\hline Мегаполис & Дата оценки & $\begin{array}{l}\text { Численность } \\
\text { населения, } \\
\text { млн человек } \\
\end{array}$ & Источник & Интернет-адрес \\
\hline Берлин & 31.12.2014 г. & 3,5 & $\begin{array}{l}\text { The Information System of the } \\
\text { Federal Health Monitoring }\end{array}$ & $\begin{array}{l}\text { http://www.gbe- } \\
\text { bund.de/gbe10/pkg_isgbe5.prc_ } \\
\text { isgbe?p_uid=gast\&p_aid=0\&p_ } \\
\text { sprache=E }\end{array}$ \\
\hline Гонконг & 2013 г. & 7,2 & WHO Mortality database & $\begin{array}{l}\text { http://www.who.int/healthinfo/ } \\
\text { mortality_data/en/ }\end{array}$ \\
\hline Лондон & $\begin{array}{l}\text { Среднегодовое } \\
\text { население } \\
2012 \text { г. }\end{array}$ & 8,3 & $\begin{array}{l}\text { GBD Compare - Public } \\
\text { Health England | Viz Hub }\end{array}$ & $\begin{array}{l}\text { http://vizhub.healthdata.org/ } \\
\text { gbd-compare/england }\end{array}$ \\
\hline $\begin{array}{l}\text { Лос- } \\
\text { Анджелес }\end{array}$ & 2014 г. & 3,9 & $\begin{array}{l}\text { Publication of the Los Angeles } \\
\text { County Department of public } \\
\text { health }\end{array}$ & $\begin{array}{l}\text { http://www.publichealth. } \\
\text { lacounty.gov/index.htm }\end{array}$ \\
\hline Москва & $\begin{array}{l}\text { Среднегодовое } \\
\text { население } \\
2014 \text { г. }\end{array}$ & 12,2 & Данные Росстата России & http://www.gks.ru/ \\
\hline Нью-Йорк & 2013 г. & 8,4 & $\begin{array}{l}\text { Department of Health Vital } \\
\text { Statistics of New York State }\end{array}$ & $\begin{array}{l}\text { http://www.health.ny.gov/ } \\
\text { statistics/vital_statistics/ } \\
\text { index.htm }\end{array}$ \\
\hline $\begin{array}{l}\text { Санкт- } \\
\text { Петербург }\end{array}$ & $\begin{array}{l}\text { Среднегодовое } \\
\text { население } \\
2014 \text { г. }\end{array}$ & 5,2 & Данные Росстата России & http://www.gks.ru/ \\
\hline Сингапур & 2013 г. & 3,8 & WHO Mortality database & $\begin{array}{l}\text { http://www.who.int/ } \\
\text { healthinfo/mortality_data/en/ }\end{array}$ \\
\hline Токио & 01.10 .2014 г. & 13,4 & $\begin{array}{l}\text { Tokyo Statistical Yearbook за } \\
\text { 1990, 2000, } 2010 \text { и } 2013 \text { г. } \\
\text { Portal site of official statistics } \\
\text { of Japan Population by Age } \\
\text { (5-Year Age Group) and Sex } \\
\text { for Prefectures - Total } \\
\text { population, October 1, } 2013\end{array}$ & $\begin{array}{l}\text { http://www.e- } \\
\text { stat.go.jp/SG1/estat/ } \\
\text { ListE.do?lid=000001118081 }\end{array}$ \\
\hline
\end{tabular}

Примечание: Приводится численность населения самого города, а не городской агломерации. Ссылки на указанные в таблице источники далее в тексте статьи не повторяются.

\section{ОБЩИЕ ТЕНДЕНЦИИ СМЕРТНОСТИ И СТРУКТУРА СМЕРТНОСТИ ПО ПРИЧИНАМ СМЕРТИ}

Вплоть до конца 1990-х годов динамика смертности в Москве и Санкт-Петербурге была сходной (рисунок 2), хотя колебания смертности в Санкт-Петербурге были большими. Но с начала 2001 г. различия в динамике весьма существенны. Из рисунка 2 видно, что показатели смертности жителей Москвы почти совсем не отреагировали на экономический кризис 1998 г., а в Санкт-Петербурге рост смертности был весьма значительным. В Москве СКС у мужчин с 1998 по 2000 г. вырос на 38, а в Санкт-Петербурге - на 312 промилльных пункта. У женщин Москвы СКС вообще снизился на 31 промилльный пункт, а вот в СанктПетербурге рост составил 104 в расчете на 1000 человек. 


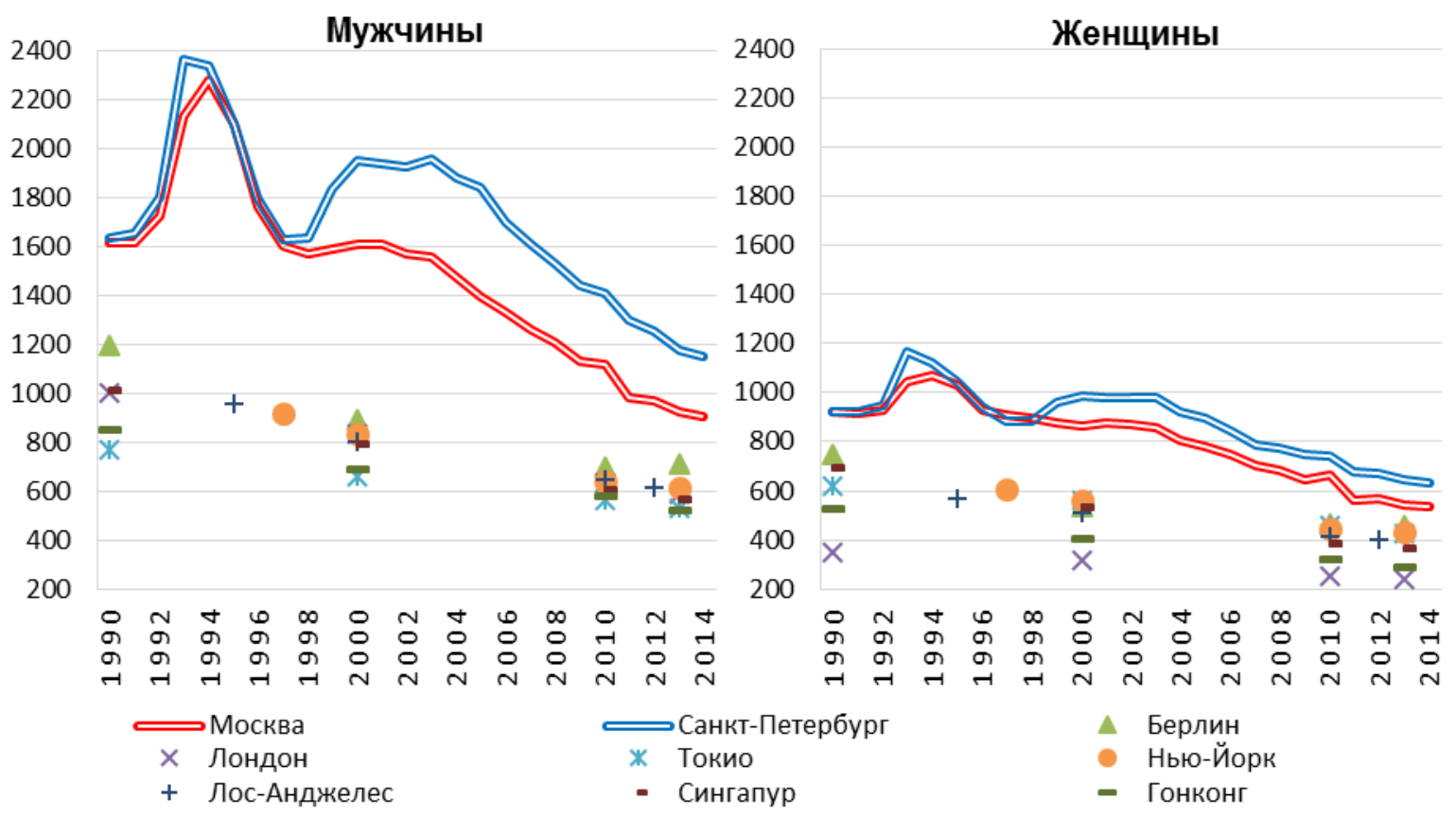

\section{Рисунок 2. Стандартизованные коэффициенты смертности в 7 мегаполисах, 1990-2014, на 100000}

В результате почти за четверть века (с 1990 по 2014 г.) СКС в Москве снизился у мужчин в 1,8 раза, а у женщин в 1,7 раза. В Санкт-Петербурге снижение составило 1,4 и 1,5 раза соответственно. Много это или мало, и как изменилось место Москвы по уровню СКС в сравнении с рассматриваемыми нами мегаполисами?

Из таблицы 2 и рисунка 2 видно, что по уровню смертности Москва как в начале, так и в конце периода, сильно отстает от всех рассматриваемых зарубежных мегаполисов. Стандартизованный коэффициент смертности в Москве превышает соответствующие показатели других мегаполисов в 1,5-2 раза. После 2000 г. отставание сокращалось, в 2013 г., по сравнению с 1990 г., разрыв по уровню смертности между Москвой и другими мегаполисами (кроме Сингапура) немного уменьшился и у мужчин, и у женщин, хотя в начале 2000-х годов он даже несколько вырос, но все же и сейчас он еще остается очень большим (рисунок 3).

Таблица 2. Стандартизованные коэффициенты смертности в некоторых мегаполисах, 1990, 2000, 2010, 2013, на 100000

\begin{tabular}{l|r|r|r|r|r|r|r|c}
\hline \multirow{2}{*}{ Мегаполис } & \multicolumn{5}{|c|}{ Мужчины } & \multicolumn{4}{c}{ Женщины } \\
\cline { 2 - 8 } & $1990 *$ & 2000 & 2010 & $2013 * *$ & $1990 *$ & 2000 & 2010 & $2013 * *$ \\
\hline Берлин & 1197,6 & 890,4 & 696,1 & 707,6 & 744,8 & 538,1 & 463,9 & 460,4 \\
Гонконг & 852,7 & 690,7 & 580,9 & 523,3 & 531,1 & 405,1 & 325,4 & 293,6 \\
Лондон & 1001,6 & 833,5 & 635,7 & 589,0 & 348,0 & 315,6 & 253,8 & 240,6 \\
Лос-Анджелес & 956,0 & 798,5 & 649,3 & 614,4 & 570,7 & 510,2 & 411,2 & 398,2 \\
Москва & 1617,2 & 1605,3 & 1120,5 & 922,2 & 922,9 & 864,4 & 664,7 & 541,0 \\
Нью-Йорк & 918,6 & 833,5 & 642,4 & 611,5 & 603,8 & 561,3 & 446,3 & 433,1 \\
Санкт-Петербург & 1632,4 & 1947,2 & 1409,0 & 1176,2 & 924,0 & 988,7 & 738,7 & 642,9 \\
Сингапур & 1017,0 & 797,0 & 609,8 & 566,0 & 699,3 & 538,3 & 385,6 & 366,3 \\
Токио & 770,9 & 657,9 & 562,9 & 528,5 & 619,0 & 562,6 & 460,8 & 428,3 \\
\hline
\end{tabular}

Примечания: *-Лос-Анджелес-1995 г., Нью-Йорк- 1997 г.; **-Лос-Анджелес - 2012 г. 


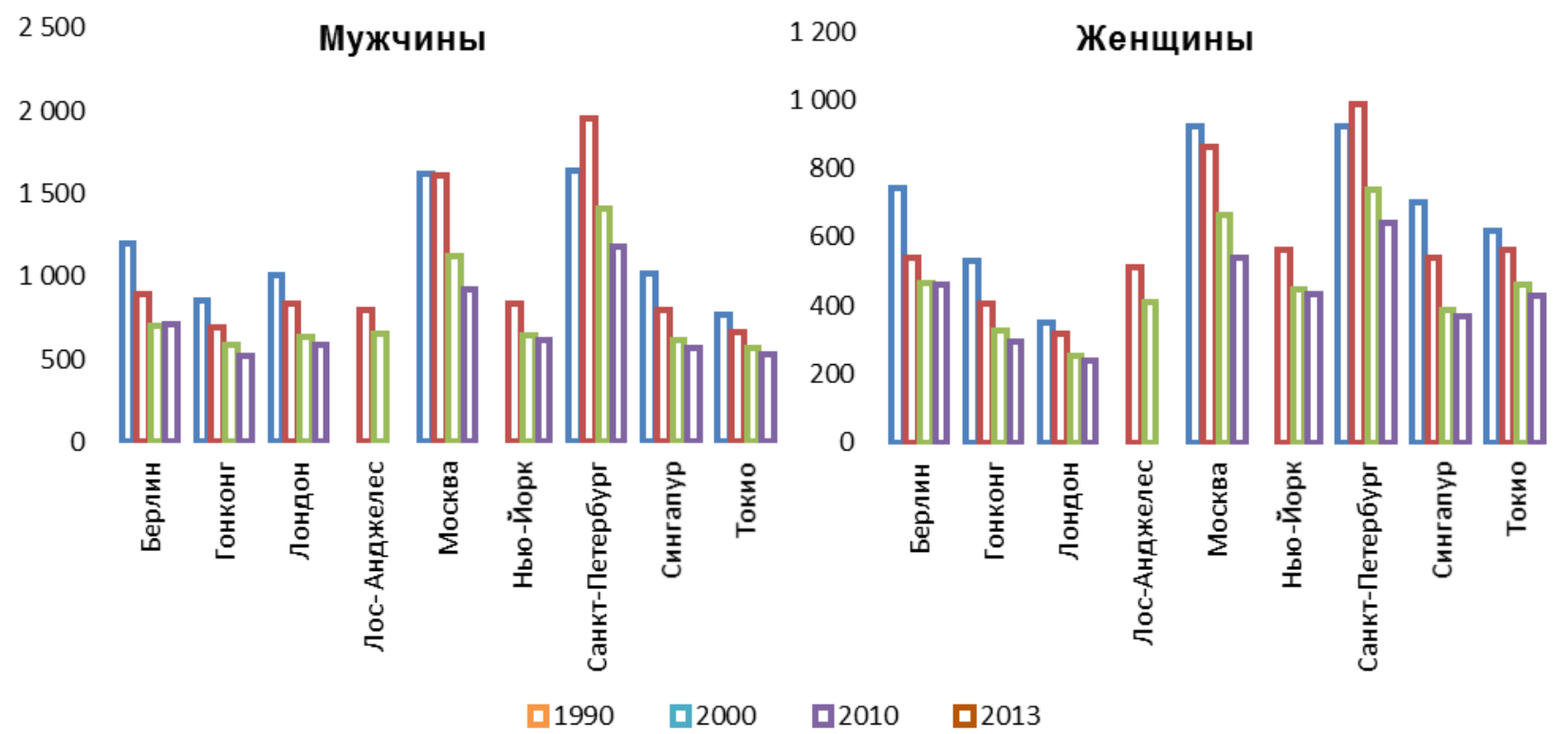

Рисунок 3. Стандартизованные коэффициенты смертности в 7 мегаполисах, 1990, 2000, 2010, 2013

Примечание: Лос-Анджелес -1995 г., Нью-Йорк - 1997 г., Лос-Анджелес - 2012 г.

Какие же причины смерти отличают уровень смертности в Москве от других мегаполисов, какие причины в последнее 25 -летие определили снижение смертности в Москве, и за счет каких снижается смертность в других мегаполисах?

В целом за рассматриваемый период основные классы причин, определяющие смертность в Москве, равно как и их ранжирование по значимости, изменений не претерпели (рисунок 4).

На протяжении всего рассматриваемого периода наибольший вклад в смертность в Москве как у мужчин, так и у женщин вносили болезни системы кровообращения (БСК). За 25 лет доля этого класса несколько снизилась (на 7,5 процентных пункта у мужчин и на 7,3 пункта у женщин). Второе место как у мужчин, так и у женщин принадлежит новообразованиям, причем у женщин к 2014 г. вклад этого класса в общую смертность вырос на 3,8 пункта. На третьем месте в Москве - «внешние причины смерти», доля которых оставалась довольно стабильной. Отдельного внимания заслуживает такая собирательная группа причин, как «Другие причины», куда вошли все остальные, не выделенные на рисунке, классы. Вклад этой группы причин в СКС вырос у мужчин в 2, а у женщин в 1,5 раза, значительную долю в ней, особенно в Москве и Берлине, занимает класс «Симптомы, признаки и неточно обозначенные состояния», включающий такие причины смерти, как старость, синдром внезапной смерти младенца, смерть по неустановленным причинам и другие симптомы и неточно обозначенные состояния. Начавшееся в 2012 г. в Москве более широкое использование при кодировании причин смерти диагноза «симптомы и неточно обозначенные состояния» привело к тому, что в 2013-2014 гг. СКС от неустановленных причин и у мужчин, и у женщин стал даже выше, чем от внешних причин. Учитывая уровень патолого-анатомической службы в Москве, мы склонны считать, что такое соотношение можно объяснить лишь тем, что «симптомы и неточно 
обозначенные состояния» часто заменяют другую причину, скорее всего, «повреждения с неустановленными намерениями».
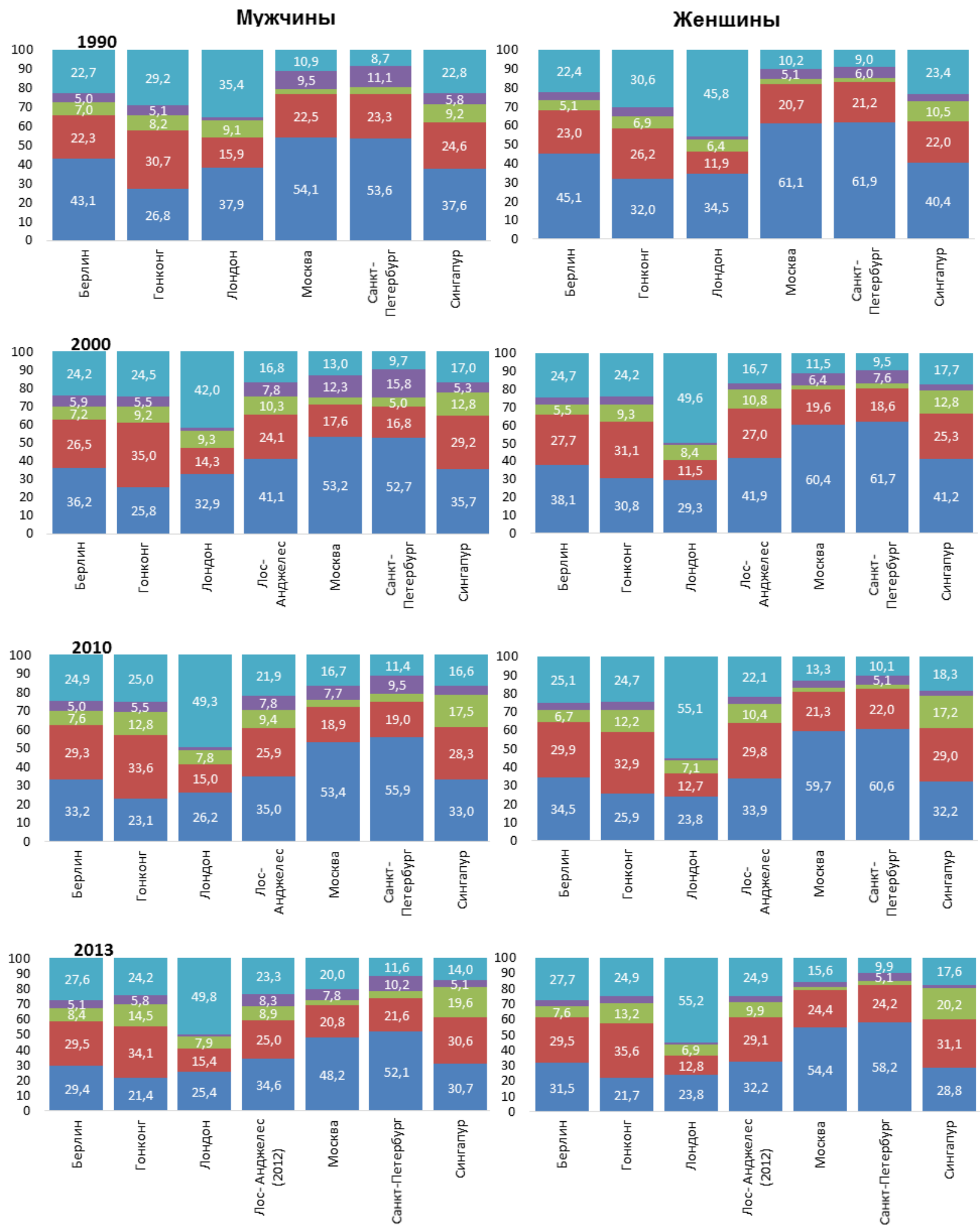

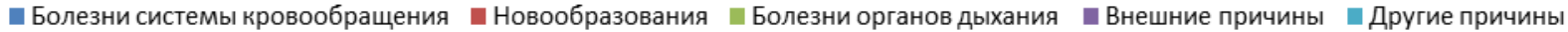

\section{Рисунок 4. Структура стандартизованного коэффициента смертности по классам} причин смерти в 7 мегаполисах, 1990, 2000, 2010, 2013, \% 
При сравнении структур смертности по причинам смерти в Москве и в выбранных мегаполисах видно, что между ними есть как сходства, так и различия (рисунок 4). Везде, за исключением Гонконга, основная доля умерших приходится на болезни системы кровообращения, на втором месте - новообразования. При этом доля БСК постепенно снижается, а новообразований растет. Но ни в одном зарубежном мегаполисе доля БСК ни разу не превышала 50\%. А вот третье место во всех рассматриваемых зарубежных мегаполисах принадлежит не внешним причинам, а болезням органов дыхания.

\section{СМЕРТНОСТЬ ПО ПРИЧИНАМ СМЕРТИ}

\section{Болезни системы кровообращения}

Подавляющее большинство умерших в Москве приходится на умерших от болезней системы кровообращения. Хотя доля этого класса причин в стандартизованном коэффициенте смертности от всех причин снижается, к 2014 г. он определял более половины величины СКС у женщин (54\%) и чуть менее половины у мужчин (47\%). 3а последнюю четверть века СКС от болезней системы кровообращения в Москве снизился у мужчин в 2,1 раза, а у женщин в 2 раза. Снижение не было постоянным в течение всего периода: в 1990-х годах наблюдался скачок в смертности от БСК - довольно резкий у мужчин и более умеренный у женщин (рисунок 5), и именно этот скачок обусловил рост общей смертности в Москве в начале 1990-х годов. В последующие годы отмечалось медленное снижение показателя. Исключение составляет 2010 г., когда подъем смертности, спровоцированный сильной жарой и смогом в летние месяцы, вызвал рост показателя за весь год [Shaposhnikov et al. 2014].

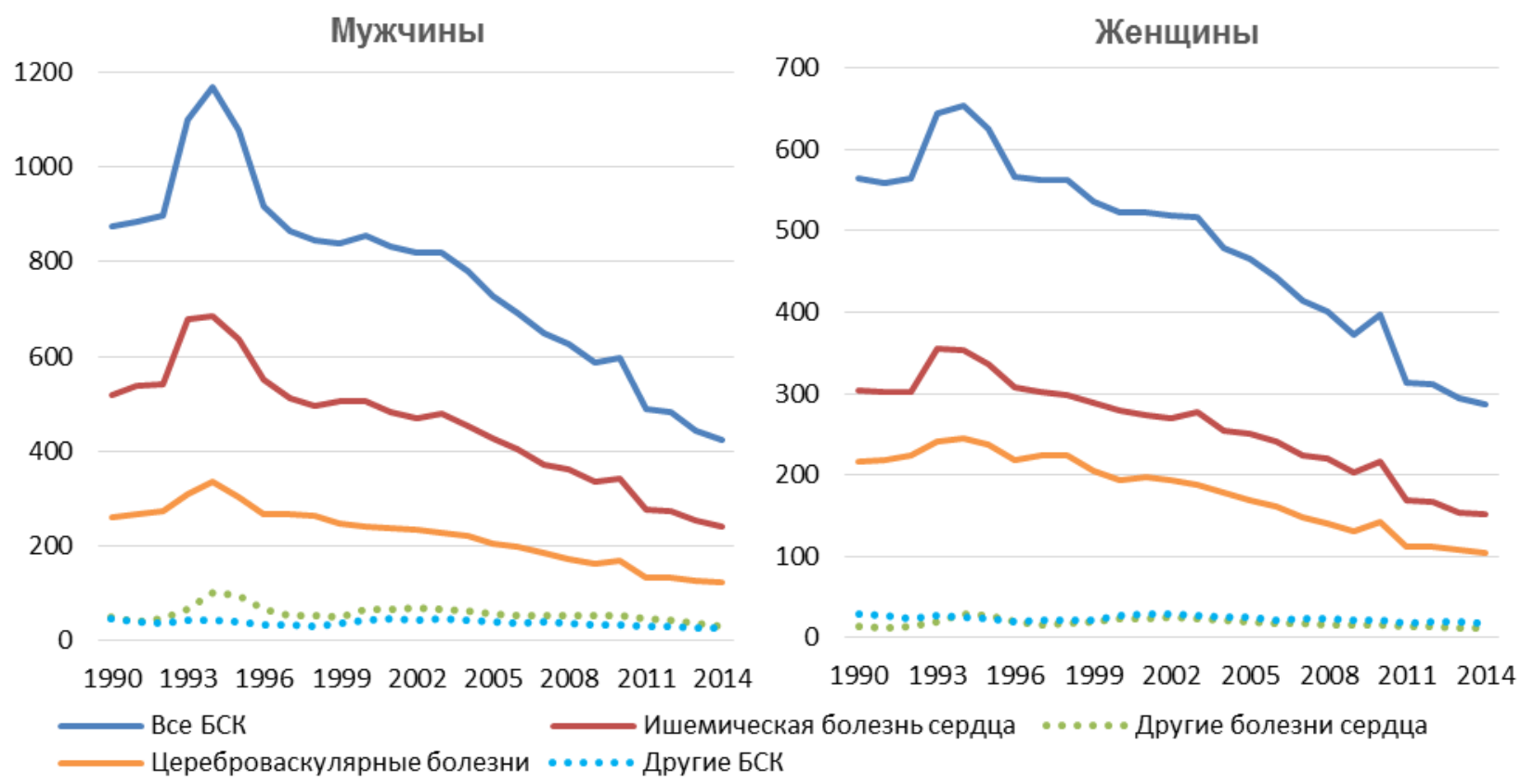

Рисунок 5. Стандартизованные коэффициенты смертности от отдельных групп болезней системы кровообращения и БСК в целом в Москве, 1990-2014, на 100000

Примечание: БСК - болезни системь кровообращения. 
Основной вклад в смертность от болезней системы кровообращения вносят смерти от ишемической болезни сердца (рисунок 5). Смертность от этой причины за 25 лет снизилась примерно в 2 раза, но ее вклад в общую смертность от БСК изменился мало и составляет 57-58\% у мужчин и 53-54\% у женщин.

Вторая основная группа причин смерти от БСК - это цереброваскулярные болезни (инсульты). За 1990-2014 гг. смертность от инсультов снизилась в 2,1 раза, но вклад ее также почти не изменился, структура смертности от БСК в Москве остается относительно стабильной.

Кроме групп «ишемическая болезнь сердца» и «цереброваскулярные болезни» часто выделяют и такую причину, как «другие болезни сердца». Бывает, что при снижении смертности от ишемической болезни одновременно растет смертность от других болезней сердца, но это чаще всего означает просто изменение в диагностике причин смерти, а не реальные изменения соотношения причин. В Москве смертность от «других болезней сердца» за рассматриваемые годы мало изменилась.

В России в целом и в большинстве ее регионов, в том числе и в Санкт-Петербурге, изменения смертности от БСК были менее благоприятными. Ее снижение в СанктПетербурге началось только после 2003 г., ему предшествовал заметный рост СКС. В отличие от Москвы, снижение смертности от ишемической болезни сердца сопровождалось ростом СКС от других болезней сердца (рисунок 6).

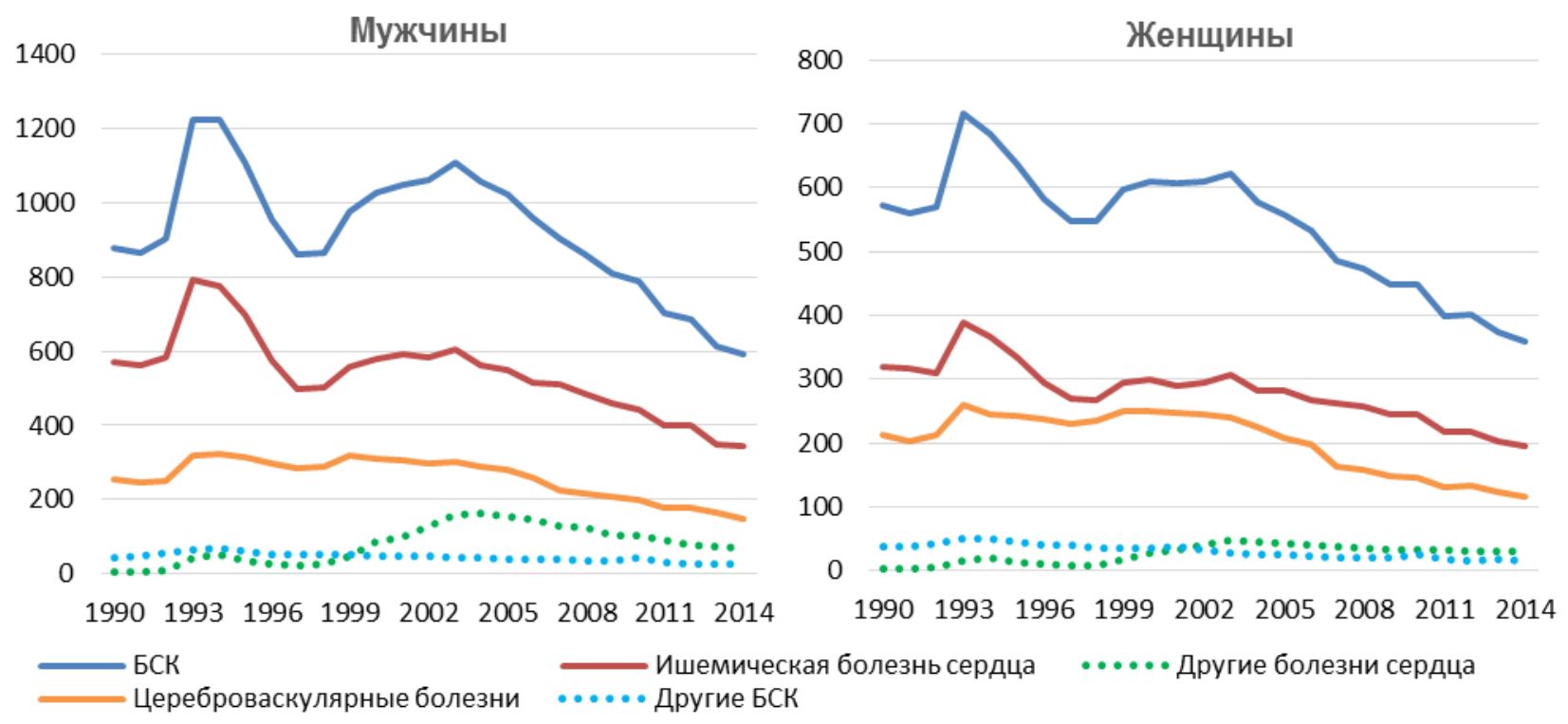

Рисунок 6. Стандартизованные коэффициенты смертности от отдельных групп болезней системы кровообращения и БСК в целом в Санкт-Петербурге, 1990-2014, на 100000

Примечание: БСК - болезни системы кровообращения.

Болезни системы кровообращения являются ведущей причиной смерти и во всех выбранных мегаполисах, но уровень смертности от БСК и входящих в этот класс причин существенно ниже, чем в Москве и, тем более, чем в Санкт-Петербурге и в России в целом. В то же время по темпам снижения смертности от БСК в последнее время Москва, как 
следует из таблицы 3, сопоставима с другими рассматриваемыми мегаполисами. Так, за период после 2000 г. показатель смертности от БСК мужчин в Москве снизился на 52\%, в других мегаполисах - на 54-65\%, женщин - на 56\%, а в других мегаполисах - на 48-71\%. Для ишемической болезни сердца снижение СКС мужчин составило $50 \%$, а в других мегаполисах - 52-75\%, снижение смертности женщин в Москве составило 55\%, в других мегаполисах - 41-72\%. Наконец, снижение смертности от цереброваскулярных болезней в Москве у мужчин - 52\%, в других мегаполисах $-54-68 \%$, у женщин - 56\%, а в других мегаполисах - 47-78\%.

Таблица 3. Стандартизованные коэффициенты смертности от всех болезней системы кровообращения, от ишемической болезни сердца и цереброваскулярных болезней, в 9 мегаполисах, 1990, 2000, 2010, 2013, на 100000

\begin{tabular}{|c|c|c|c|c|c|c|c|c|}
\hline \multirow[b]{2}{*}{ Мегаполис } & \multicolumn{4}{|c|}{ Мужчины } & \multicolumn{4}{|c|}{ Женщины } \\
\hline & $1990^{*}$ & 2000 & 2010 & $2013 * *$ & $1990^{*}$ & 2000 & 2010 & $2013 * *$ \\
\hline \multicolumn{9}{|c|}{ Болезни системы кровообращения } \\
\hline Берлин & 516,1 & 322,2 & 231,0 & 207,9 & 335,8 & 205,1 & 160,2 & 144,9 \\
\hline Гонконг & 228,8 & 177,9 & 134,3 & 112,2 & 170,2 & 124,8 & 84,1 & 63,8 \\
\hline Лондон & 379,8 & 274,5 & 166,5 & 149,4 & 213,6 & 164,6 & 109,6 & 101,9 \\
\hline Лос-Анджелес & н.д & 327,9 & 227,5 & 212,4 & н.д & 214,0 & 139,4 & 128,2 \\
\hline Москва & 874,8 & 853,3 & 597,9 & 444,1 & 563,5 & 521,8 & 397,0 & 294,4 \\
\hline Нью-Йорк & н.Д & н.д & н.д & н.д & н.д & н.д & н.д & н.д \\
\hline Санкт-Петербург & 875,5 & 1026,0 & 788,3 & 613,4 & 571,9 & 610,4 & 447,8 & 374,0 \\
\hline Сингапур & 382,8 & 284,7 & 201,2 & 173,7 & 282,7 & 221,7 & 124,3 & 105,6 \\
\hline Токио & н.д & н.д & н.д & н.Д & н.д & н.д & н.д & н.д \\
\hline \multicolumn{9}{|c|}{ Ишемическая болезнь сердияа } \\
\hline Берлин & 219,1 & 150,3 & 105,9 & 90,2 & 107,6 & 76,8 & 57,2 & 44,2 \\
\hline Гонконг & 91,5 & 72,1 & 64,0 & 50,9 & 57,5 & 43,5 & 31,6 & 22,2 \\
\hline Лондон & 268,4 & 188,2 & 109,5 & 97,7 & 127,8 & 97,1 & 58,7 & 54,0 \\
\hline Лос-Анджелес & 269,4 & 217,0 & 137,1 & 126,1 & 164,8 & 129,9 & 72,7 & 63,7 \\
\hline Москва & 518,7 & 504,6 & 342,7 & 252,9 & 303,4 & 279,5 & 216,4 & 154,5 \\
\hline Нью-Йорк & 355,0 & 321,1 & 212,7 & 189,3 & 246,1 & 220,9 & 146,3 & 130,6 \\
\hline Санкт-Петербург & 569,4 & 579,1 & 442,9 & 348,1 & 319,6 & 298,8 & 244,5 & 203,1 \\
\hline Сингапур & 214,7 & 166,7 & 121,9 & 97,7 & 132,4 & 111,5 & 64,1 & 46,1 \\
\hline Токио*** & 143,9 & 93,6 & 77,6 & 70,2 & 92,2 & 56,4 & 45,0 & 40,7 \\
\hline \multicolumn{9}{|c|}{ Цереброваскулярные болезни } \\
\hline Берлин & 90,0 & 45,0 & 34,7 & 29,7 & 72,5 & 32,9 & 27,9 & 24,3 \\
\hline Гонконг & 78,6 & 64,1 & 40,6 & 35,2 & 67,0 & 48,0 & 28,2 & 23,1 \\
\hline Лондон & 70,0 & 51,8 & 33,8 & 30,9 & 60,3 & 45,9 & 32,1 & 30,3 \\
\hline Лос-Анджелес & 51,5 & 48,0 & 30,6 & 27,3 & 43,1 & 40,7 & 24,8 & 23,7 \\
\hline Москва & 261,8 & 240,0 & 170,3 & 125,9 & 215,7 & 193,1 & 142,5 & 107,9 \\
\hline Нью-Йорк & 29,5 & 24,8 & 17,5 & 16,8 & 24,6 & 20,9 & 15,4 & 16,4 \\
\hline Санкт-Петербург & 254,0 & 310,5 & 200,0 & 166,6 & 212,9 & 248,8 & 145,1 & 123,4 \\
\hline Сингапур & 113,1 & 71,9 & 45,7 & 44,2 & 103,8 & 73,9 & 37,7 & 37,5 \\
\hline Токио & 100,9 & 76,4 & 51,9 & 43,4 & 76,5 & 51,9 & 29,5 & 24,4 \\
\hline
\end{tabular}

Примечания: *-Лос-Анджелес -1995 г., Нью-Йорк- 1997 г.; **-Лос-Анджелес - 2012 г.; *** - по Токио приводятся показатели по умериим от всех болезней сердия, а не только от ичемической болезни.

Отличие Москвы от крупнейших мегаполисов мира по уровню смертности от болезней системы кровообращения все еще остается весьма значительным, что, вероятно, связано с общим отставанием российского здравоохранения. Например, в настоящее время разработаны и повсеместно применяются в развитых странах мира чрезвычайно эффективные, но дорогостоящие методы лечения инсульта и постинсультной реабилитации. Они, к сожалению, не используются российским общедоступным 
здравоохранением, отсюда и отмеченное выше различие московских (российских) и западных показателей. И, конечно, очень важный фактор - это расходы на здравоохранение, которые, как известно, в настоящее время сокращаются.

\section{Новообразования}

Смертность от новообразований (в основном злокачественных) занимает второе место в структуре причин смерти жителей Москвы (как мужчин, так и женщин). Удельный вес этих причин в общей смертности в 2014 г. составлял 21\% у мужчин и 25\% у женщин. Доля доброкачественных новообразований в Москве, как и в других городах, мала и составляет около $1 \%$ от всех новообразований у мужчин и 1,5\% - у женщин. Поэтому обычно анализируется смертность от злокачественных новообразований.

По сравнению с другими причинами отличия Москвы по этому виду смертности от Санкт-Петербурга и других выбранных мегаполисов не так велики, и к 2013 г. эти различия даже немного уменьшились за счет более медленного снижения показателей в других мегаполисах. В течение рассматриваемого периода отмечалось также сближение уровней смертности мужчин и женщин за счет более быстрых темпов ее снижения у мужчин.

Таблица 4. Стандартизованные коэффициенты смертности от новообразований в 9 мегаполисах, 1990, 2000, 2010, 2013, на 100000

\begin{tabular}{l|r|r|r|r|r|r|r|r}
\hline \multirow{2}{*}{ Мегаполис } & \multicolumn{4}{|c|}{ Мужчины } & \multicolumn{4}{c}{ Женщины } \\
\cline { 2 - 8 } & $1990 *$ & 2000 & 2010 & $2013 * *$ & $1990 *$ & 2000 & 2010 & $2013 * *$ \\
\hline Берлин & 267,2 & 235,6 & 203,7 & 208,6 & 171,4 & 149,1 & 138,9 & 135,9 \\
Гонконг & 261,5 & 241,7 & 195,2 & 178,3 & 139,1 & 126,2 & 106,9 & 104,4 \\
Лондон & 159,2 & 119,2 & 95,6 & 90,6 & 73,4 & 64,8 & 58,7 & 54,9 \\
Лос-Анджелес & н.Д. & 192,5 & 168,2 & 153,5 & н.д. & 137,7 & 122,4 & 115,9 \\
Москва & 364,0 & 283,3 & 212,0 & 191,7 & 191,5 & 169,1 & 141,5 & 131,7 \\
Нью-Йорк*** & 210,7 & 192,9 & 161,8 & 151,2 & 151,5 & 140,7 & 118,7 & 112,5 \\
Санкт-Петербург & 380,3 & 328,0 & 268,1 & 254,6 & 196,3 & 184,2 & 162,6 & 155,6 \\
Сингапур & 250,1 & 232,8 & 172,4 & 173,3 & 154,2 & 136,4 & 111,6 & 113,9 \\
Токио*** & 229,7 & 223,2 & 191,9 & 181,3 & 120,4 & 117,5 & 100,1 & 97,0 \\
\hline
\end{tabular}

Примечания: *-Нью-Йорк- 1997 г.; **-Лос-Анджелес- 2012 г.; ***-злокачественные новообразования.

Хотя стандартизованный коэффициент смертности от новообразований в Москве ниже, чем в Санкт-Петербурге и Берлине, он заметно выше, чем в других взятых для сравнения мегаполисах (таблица 4).

Как и в других мегаполисах, структура смертности от новообразований в Москве различается у мужчин и женщин (рисунок 7).

В течение последних 25 лет смертность от новообразований в Москве постоянно снижалась, у мужчин она снизилась в 1,9 раза, у женщин - в 1,5 раза (рисунок 8). Снижалась смертность от новообразований и в Санкт-Петербурге, но темпы этого снижения были намного ниже, чем в Москве. В результате различие в уровне смертности от новообразований между двумя российскими мегаполисами выросло как у мужчин, так и у женщин. 

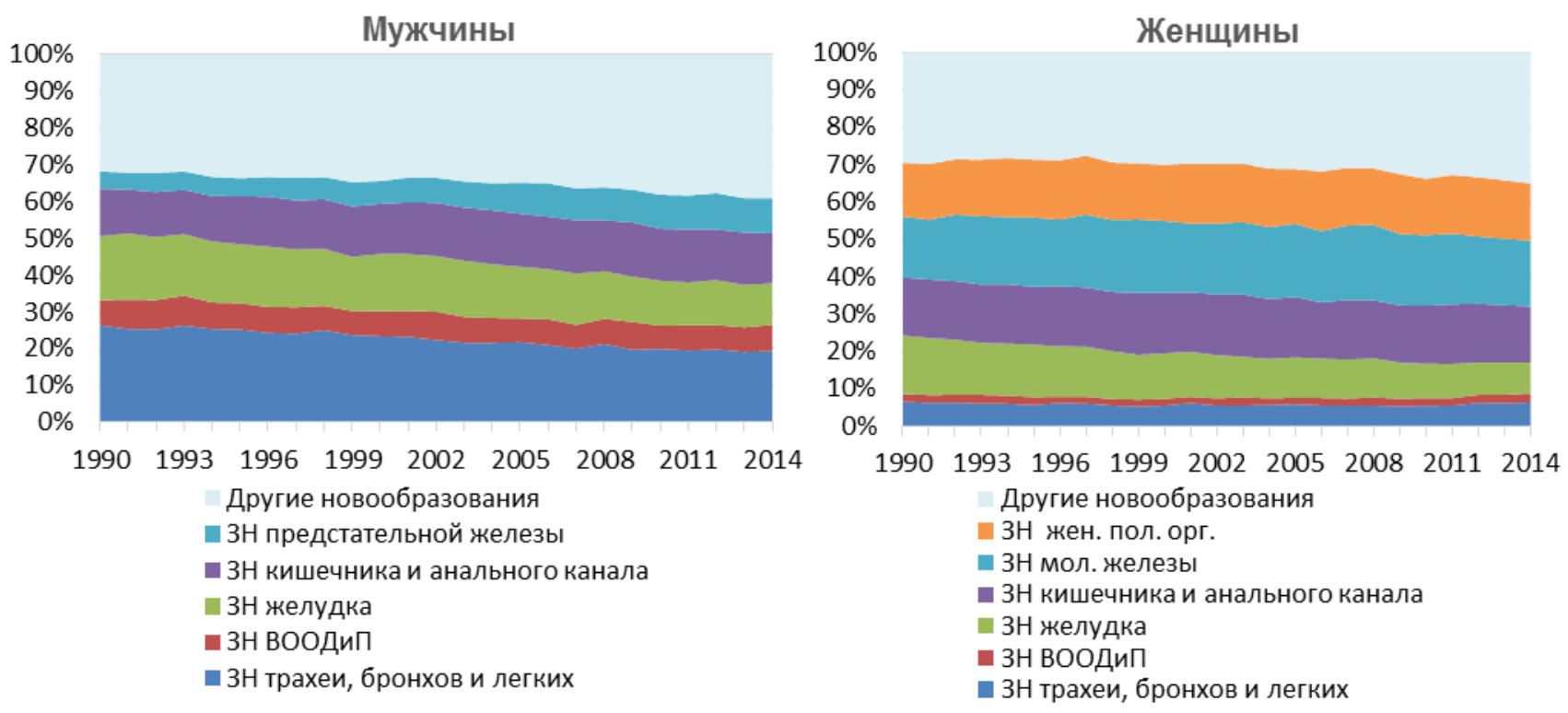

\section{Рисунок 7. Структура стандартизованного коэффициента смертности от новообразований в Москве, 1990-2014, \%}

Примечания: ЗН - злокачественные новообразования; ЗН ВООДиП - злокачественные новообразования верхних отделов органов дыхания и пищевода; другие новообразования включают и доброкачественные

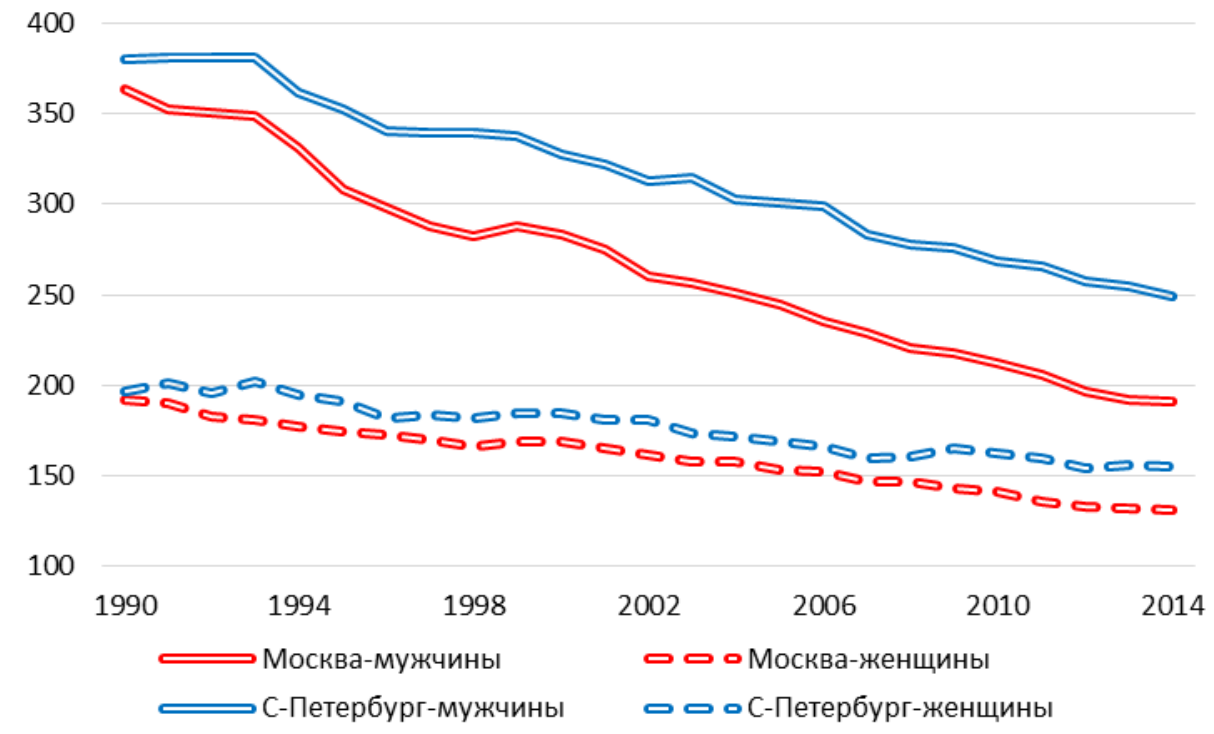

\section{Рисунок 8. Стандартизованные коэффициенты смертности от новообразований в Москве и Санкт-Петербурге, 1990-2014, на 100000}

\section{Новообразования органов дыхания и пищевода}

Если не учитывать собирательную группу причин «другие новообразования», то первое место среди всех причин мужских смертей, относящихся к классу новообразований (26,5\% в 2014 г.), принадлежит злокачественным новообразованиям органов дыхания и пищевода. У женщин эта локализация занимает третье место. В эту группу мы включили две подгруппы причин смерти: злокачественные новообразования трахеи, бронхов и легких и 
злокачественные новообразования верхних отделов органов дыхания и пищевода.

В сравнении с другими рассматриваемыми мегаполисами смертность от злокачественных новообразований трахеи, бронхов и легких у женщин в Москве выглядит благополучно (таблица 5). У мужчин в начале рассматриваемого периода смертность от этой локализации была выше, чем во всех зарубежных мегаполисах. К 2013 г. ее уровень снизился более чем в 2,6 раза и стал одним из наименьших в рассматриваемых мегаполисах. В смертности от злокачественных новообразований верхних отделов органов дыхания и пищевода таких сильных различий нет.

\section{Таблица 5. Стандартизованные коэффициенты смертности от злокачественных новообразований органов дыхания и пищевода в 7 мегаполисах, 1990, 2000, 2010, 2013, на 100000}

\begin{tabular}{|c|c|c|c|c|c|c|c|c|}
\hline \multirow{2}{*}{ Мегаполис } & \multicolumn{4}{|c|}{ Мужчины } & \multicolumn{4}{|c|}{ Женщины } \\
\hline & $1990 *$ & 2000 & 2010 & $2013 * *$ & $1990 *$ & 2000 & 2010 & $2013 * *$ \\
\hline \multicolumn{9}{|c|}{ Злокачественнье новообразования трахеи, бронхов и легких (С33,С34) } \\
\hline Берлин & 74,8 & 64,1 & 59,0 & 58,3 & 18,4 & 21,7 & 27,0 & 29,6 \\
\hline Гонконг & 88,2 & 79,9 & 60,1 & 54,2 & 36,2 & 29,5 & 24,1 & 24,2 \\
\hline Лондон & 86,7 & 58,9 & 43,7 & 41,0 & 27,9 & 25,2 & 24,1 & 22,9 \\
\hline Лос-Анджелес & 63,5 & 52,6 & 39,7 & 33,5 & 32,5 & 28,0 & 23,8 & 21,5 \\
\hline Москва & 96,2 & 66,3 & 42,3 & 36,6 & 12,5 & 9,2 & 7,6 & 8,0 \\
\hline Санкт-Петербург & 104,1 & 82,9 & 59,6 & 56,7 & 13,8 & 10,8 & 10,5 & 9,5 \\
\hline Сингапур & 72,8 & 64,4 & 47,4 & 45,7 & 24,8 & 20,6 & 17,4 & 18,4 \\
\hline \multicolumn{9}{|c|}{ Злокачественные новообразования верхних отделов органов дыхания и пищевода (С00-С15) } \\
\hline Берлин & 17,2 & 17,4 & 14,0 & 15,6 & 3,7 & 4,6 & 4,2 & 3,8 \\
\hline Гонконг & 34,1 & 24,5 & 16,3 & 14,6 & 7,6 & 5,6 & 3,6 & 3,5 \\
\hline Лондон & 14,0 & 14,1 & 12,5 & 11,7 & 4,9 & 4,7 & 4,1 & 3,9 \\
\hline Лос-Анджелес & н.Д & 10,0 & 9,0 & 8,4 & $\ldots$ & 2,7 & 2,4 & 2,3 \\
\hline Москва & 24,7 & 19,2 & 13,4 & 12,8 & 3,8 & 3,0 & 2,9 & 3,1 \\
\hline Санкт-Петербург & 31,0 & 28,3 & 22,7 & 18,0 & 6,2 & 4,4 & 4,0 & 3,4 \\
\hline Сингапур & 31,9 & 21,8 & 14,5 & 14,1 & 9,6 & 5,4 & 3,8 & 3,2 \\
\hline
\end{tabular}

Примечания: *-Лос-Анджелес-1995 г., Нью-Йорк- 1997 г.; **-Лос-Анджелес - 2012 г.

У мужчин доля умерших от обеих рассматриваемых локализаций рака во всех новообразованиях постепенно снижается. Это происходит, в основном, за счет снижения смертности от рака трахеи бронхов и легких (рисунок 9). Смертность же от рака верхних отделов органов дыхания и пищевода в последние 5 лет не меняется. У женщин при гораздо более низком уровне смертности от новообразований трахеи, бронхов и легких она прекратила свое снижение в середине 2010-х годов, а от новообразований верхних отделов органов дыхания и пищевода стабилизировалась на уровне середины 1990-х. Однако в 2014 г., как у мужчин, так и у женщин, зафиксирован рост смертности от этих локализаций рака.

Для снижения смертности от злокачественных новообразований важно как можно раньше обнаружить болезнь. К сожалению, в России и ее регионах, включая Москву, почти половина диагнозов в 2014 г. была поставлена на III-IV стадиях болезни [Каприн и др. 2015: 23]. Для рака желудка, поджелудочной железы, печени, органов дыхания и пищевода доля диагнозов, поставленных на поздних стадиях, самая высокая [Каприн и др. 2015: 60-149]. 
Наши расчеты, основанные на данных Минздрава ${ }^{4}$, показали, что в 2004 г. (первый год, по которому у нас есть соответствующие данные) для злокачественных новообразований трахеи, бронхов и легких доля поздних диагнозов составляла 67\%, а к 2014 г. (последний год, для которого у нас есть данные) она выросла до 74\%. Для рака верхних отделов органов дыхания и пищевода доля поздних диагнозов в 2004 г. была еще выше - 77\%, но за 10 лет она снизилась до $71 \%$.

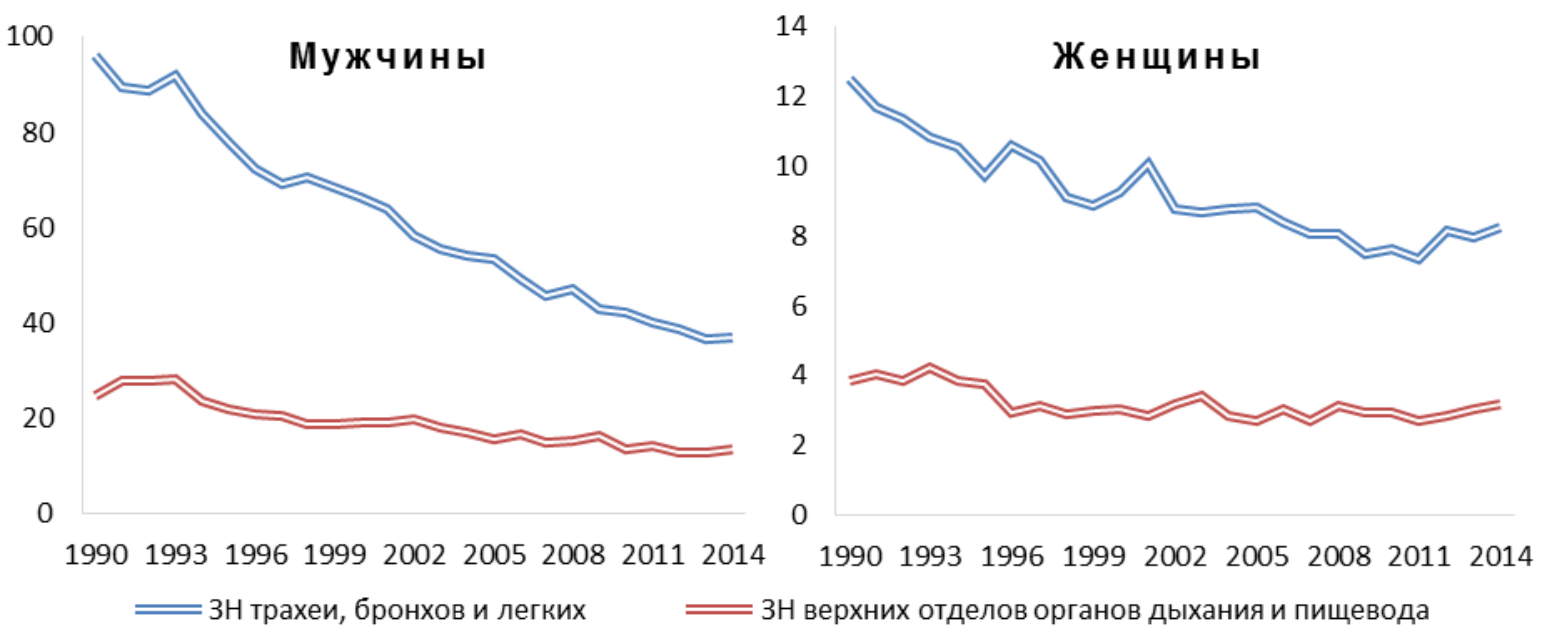

Рисунок 9. Стандартизованные коэффициенты смертности от злокачественных новообразований органов дыхания и пищевода в Москве, 1990-2014, на 100000

\section{Новообразования молочной жселезы и женских половых органов}

Злокачественные новообразования молочной железы и половых органов занимают первое место в структуре онкологической смертности женщин. От этой причины в 2014 г. в Москве погибло почти 33\% всех умерших от новообразований женщин (18\% приходится на рак молочной железы и 15\% - на рак женских половых органов). С 1990 по 2014 г. динамика смертности женщин от новообразований молочной железы при тенденции к снижению не была равномерной. В течение всех 1990-х годов и в первой половине 2000-х отмечались существенные колебания показателей смертности от этой причины и только с конца 2000х годов наметилось ее устойчивое снижение (рисунок 10).

Смертность от злокачественных новообразований обеих локализаций в Москве почти все время немного ниже, чем в Санкт-Петербурге, но зарубежным мегаполисам Москва проигрывает, особенно в смертности от злокачественных новообразований женских половых органов (таблица 6). Среди рассматриваемых мегаполисов выделяется Лондон, где смертность от злокачественных новообразований этих локализаций, в отличие от злокачественных новообразований органов дыхания и пищевода, очень низка.

\footnotetext{
4 Здесь и далее за период до 2014 г. используются данные государственной медицинской статистики (форма №35 «Сведения о больных со злокачественными новообразованиями за ...год»).
} 


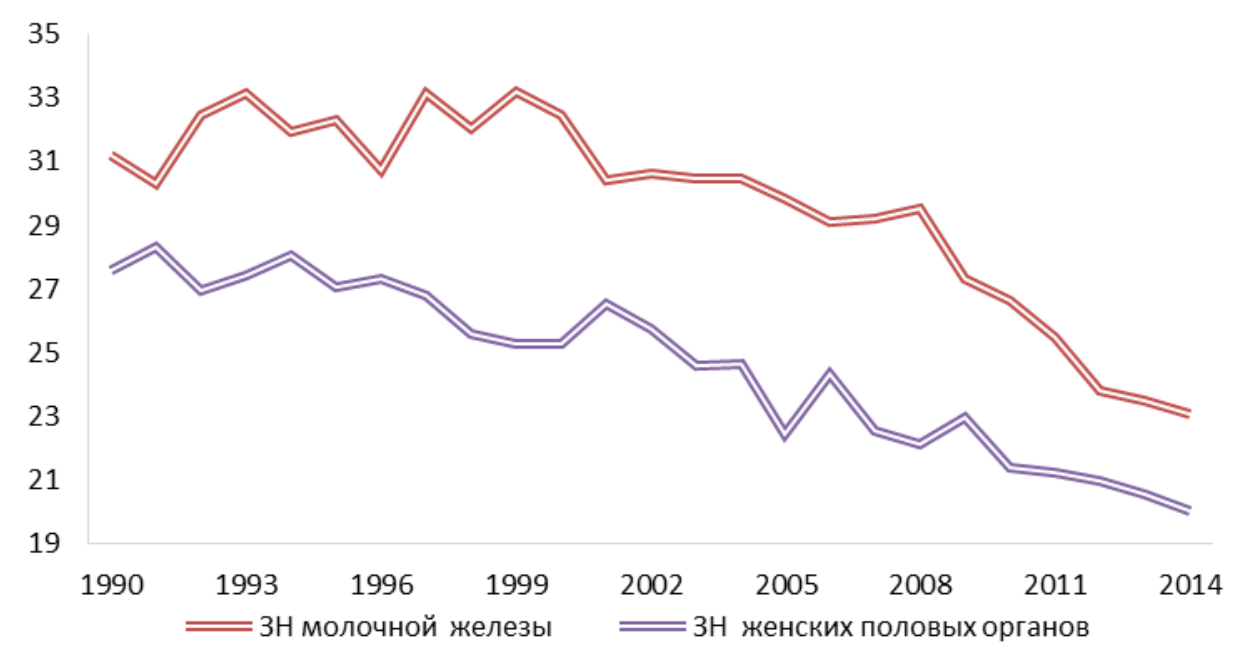

Рисунок 10. Стандартизованные коэффициенты смертности от злокачественных новообразований молочной железы и женских половых органов в Москве. 1990-2014 гг., на 100000

Таблица 6. Стандартизованные коэффициенты смертности от злокачественных новообразований молочной железы и женских половых органов в 7 мегаполисах, 1990, 2000, 2010, 2013, на 100000

\begin{tabular}{|c|c|c|c|c|c|c|c|c|}
\hline \multirow{3}{*}{ Мегаполис } & \multicolumn{8}{|c|}{ Злокачественные новообразования } \\
\hline & \multicolumn{4}{|c|}{ Молочной железы (C50) } & \multicolumn{4}{|c|}{ Женских половых органов (C51-С58) } \\
\hline & $1990^{*}$ & 2000 & 2010 & $2013 * *$ & $1990^{*}$ & 2000 & 2010 & $2013 * *$ \\
\hline Берлин & 30,5 & 27,7 & 22,5 & 22,7 & 20,2 & 15,4 & 11,8 & 13,4 \\
\hline Гонконг & 12,0 & 11,8 & 12,2 & 11,9 & 12,1 & 9,3 & 9,8 & 9,9 \\
\hline Лондон & 11,2 & 9,3 & 7,5 & 6,8 & 5,6 & 4,9 & 4,0 & 3,8 \\
\hline Лос-Анджелес & 28,5 & 22,8 & 20,2 & 20,0 & н.д & 17,0 & 15,5 & 14,3 \\
\hline Москва & 31,2 & 32,5 & 26,6 & 23,5 & 27,6 & 25,3 & 21,4 & 20,6 \\
\hline Санкт-Петербург & 28,6 & 32,2 & 30,8 & 27,4 & 28,9 & 27,2 & 26,5 & 27,1 \\
\hline Сингапур & 20,0 & 18,8 & 19,0 & 20,8 & 16,9 & 16,1 & 12,3 & 12,6 \\
\hline
\end{tabular}

Примечания: *-Лос-Анджелес-1995 г., Нью-Йорк- 1997 г.; **-Лос-Анджелес - 2012 г.

В отличие от Санкт-Петербурга, где показатели почти не менялись, в Москве за 25 лет смертность от новообразований двух групп новообразований снизились в 1,4 раза, причем основное снижение пришлось на последние годы.

В Москве снижение смертности от рака молочной железы сочетается с ростом числа заболеваний этой формой рака. «Эти «ножницы» между количествами заболевших и умерших безусловно положительное и достаточно редкое явление среди показателей состояния здоровья населения России» [Ревич и др. 2014]. При этом до сих пор большая доля заболеваний раком этой локализации выявляется в Москве на III-IV-ой стадиях: в 2014 г. - 31\% (в 2004 г. эта доля была 34\%), что говорит о недостаточно эффективной работе системы профилактики [Каприн и др. 2015: 10-12]. С другой стороны, число рентгеновских профилактических исследований молочной железы, проведенных в Москве за последние годы, выросло с 236 тыс. в 2004 г. до 557 тыс. в 2014 г. В расчете на 1000 женщин в возрасте старше 35 лет число сделанных обследований в 2014 г. по сравнению с 2004 г. выросло с 70 до 138, т.е. почти в 2 раза. Эти показатели далеки от идеальных, но именно рост 
профилактических обследований стал одной из причин, которые привели к снижению смертности от рака молочной железы [Аксель 2012].

Смертность от злокачественных новообразований женских половых органов при некоторых скачках медленно снижалась в течение всего периода. За 25 лет смертность от рака женских половых органов, как и рака молочной железы, в Москве снизилась в 1,4 раза (рисунок 11).

В большинстве случаев в Москве рак шейки и тела матки выявляют на ранних стадиях заболевания. В 2014 г. 79\% выявленных заболеваний пришлось на I-ю - II-ю стадии болезни. Но за 10 лет с 2004 г. эта доля почти не изменилась (76\% в 2004 г.). Если злокачественные новообразования шейки матки выявляются на ранних стадиях (69\% в 2014 г. и $65 \%$ в 2004 г.), то рак яичников в основном выявляется только на III-IV стадиях (66\% в 2014 г. и $62 \%$ в 2004 г., т.е. роста доли случаев ранней диагностики нет), что имеет своим следствием высокую смертность от рака этой локализации. При диагностике злокачественных новообразований женской половой сферы также большую роль играют профилактические осмотры и ультразвуковые обследования. Но, по мнению специалистов, доля больных раком шейки матки, обнаруживаемых при их проведении, увеличивается очень медленно [Аксель 2009].

Около четверти погибших от злокачественных новообразований женских половых органов в Москве умирают от рака шейки матки. Между тем, в отличие от других злокачественных новообразований, смертность от рака шейки матки может быть доведена до минимальных уровней.

В последние годы в большинстве развитых стран для предотвращения смертности от этой причины стали использовать прививки от вируса папилломы человека (ВПЧ). Несколько видов этого вируса считаются причиной возникновения (провоцируя развитие) абсолютного большинства случаев рака шейки матки, в отсутствии ВПЧ рак шейки матки не встречается. Современные врачи считают необходимым прививать всех девочек и молодых женщин в возрастном диапазоне от 12 лет, которые еще не начинали жить половой жизнью. Во многих развитых странах Европы, в США и Канаде эти прививки стали в последние годы обязательными для девочек. В развитых странах такие прививки можно сделать не только девочкам, но и мальчикам [ВОЗ 2015; WHO 2014].

В России также можно сделать такую прививку, но в большинстве регионов это платная процедура. Москва входит в небольшой перечень регионов, в которых эту прививку (по желанию) можно сделать бесплатно. С конца 2000-х годов прививка «Вакцинация (девочки) против вируса папилломы человека» входит в ежегодный региональный календарь профилактических прививок ${ }^{5}$. Прививку рекомендуется делать девочкам в возрасте 13 лет. Результаты такой вакцинации видны не сразу - основная смертность от рака шейки матки приходится на возраст старше 35 лет.

5 См. Приказ Руководителя Департамента здравоохранения г. Москвы от 16.01.2009 №9 «О календаре профилактических прививок и календаре профилактических прививок по эпидемическим показаниям». http://lawru.info/dok/2009/01/16/n765383.htm 


\section{Новообразования органов пищеварения}

Второе место в структуре смертности от новообразований в Москве как у мужчин, так и у женщин принадлежит злокачественным новообразованиям органов пищеварения. Эта группа причин смерти включает основные подгруппы: злокачественные новообразования желудка и злокачественные новообразования кишечника и анального канала. В 2014 г. на эти локализации приходилось $25 \%$ от всех умерших от новообразований мужчин и $23 \%$ женщин.

Как и в предыдущих случаях, по смертности от злокачественных новообразований органов пищеварения Москва находится в лучшем положении, чем второй российский мегаполис - Санкт-Петербург, но уступает зарубежным мегаполисам, особенно по смертности от злокачественных новообразований желудка (таблица 7). В 2013 г. по смертности от рака желудка Москва превосходила зарубежные мегаполисы в среднем в 3 раза. Среди рассматриваемых мегаполисов обращает на себя внимание Лондон, где смертность от злокачественных новообразований этих локализаций очень мала. Мала она и в Лос-Анджелесе. Разница в уровне смертности от злокачественных новообразований кишечника и анального канала меньше, но все равно довольно большая. Скорее всего, это связано именно с тем, что в этих мегаполисах давно и хорошо поставлена профилактика и скрининг этих болезней.

Таблица 7. Стандартизованные коэффициенты смертности от злокачественных новообразований органов пищеварения в 7 мегаполисах, 1990, 2000, 2010, 2013, на 100000

\begin{tabular}{|c|c|c|c|c|c|c|c|c|}
\hline \multirow{2}{*}{ Мегаполис } & \multicolumn{4}{|c|}{ Мужчины } & \multicolumn{4}{|c|}{ Женщины } \\
\hline & 1990* & 2000 & 2010 & $2013 * *$ & $1990^{*}$ & 2000 & 2010 & $2013 * *$ \\
\hline \multicolumn{9}{|c|}{ Злокачественные новообразования желудка (С16) } \\
\hline Берлин & 20,9 & 13,7 & 8,9 & 8,4 & 12,0 & 6,1 & 4,9 & 4,0 \\
\hline Гонконг & 17,4 & 13,8 & 10,4 & 8,3 & 8,5 & 7,5 & 5,2 & 4,3 \\
\hline Лондон & 11,9 & 6,9 & 4,4 & 4,0 & 3,1 & 2,4 & 1,8 & 1,6 \\
\hline Лос-Анджелес & н.Д & 8,0 & 7,2 & 6,2 & н.д & 4,4 & 3,7 & 3,5 \\
\hline Москва & 63,3 & 44,1 & 26,0 & 22,2 & 30,0 & 20,7 & 13,0 & 11,4 \\
\hline Санкт-Петербург & 67,5 & 48,0 & 33,6 & 31,2 & 31,4 & 22,5 & 16,3 & 12,5 \\
\hline Сингапур & 31,4 & 20,1 & 12,1 & 10,9 & 15,1 & 12,2 & 6,3 & 6,3 \\
\hline \multicolumn{9}{|c|}{ Злокачественные новообразования кишечника и анального канала (C17-C21) } \\
\hline Берлин & 28,0 & 26,8 & 18,3 & 20,7 & 21,9 & 17,0 & 14,4 & 11,6 \\
\hline Гонконг & 25,4 & 26,4 & 25,2 & 24,0 & 16,7 & 18,0 & 15,4 & 15,3 \\
\hline Лондон & 19,4 & 15,8 & 13,9 & 13,5 & 12,4 & 10,1 & 9,1 & 8,4 \\
\hline Лос-Анджелес & 22,6 & 18,6 & 14,9 & 14,5 & 14,6 & 13,5 & 10,4 & 9,6 \\
\hline Москва & 47,0 & 38,6 & 29,9 & 27,3 & 29,8 & 27,4 & 22,0 & 20,2 \\
\hline Санкт-Петербург & 48,1 & 46,2 & 37,3 & 34,6 & 32,4 & 33,1 & 24,1 & 24,7 \\
\hline Сингапур & 26,0 & 30,6 & 26,6 & 23,6 & 23,7 & 24,4 & 15,9 & 17,7 \\
\hline
\end{tabular}

Примечания: *-Лос-Анджелес-1995 г., Нью-Йорк- 1997 г.; **-Лос-Анджелес - 2012 г.

В динамике смертности от рассматриваемых групп причин есть общие черты и различия. Общее - это снижение показателей за рассматриваемый период. Различие заключается в темпах снижения этих показателей.

Из всех рассматриваемых локализаций рака смертность от рака желудка в Москве снизилась сильнее всего - в 2,9 раза у мужчин и в 2,7 раза у женщин (рисунок 11). При этом 
доля этой локализации в общем числе смертей от всех новообразований за последние четверть века снизилась на $6 \%$ у мужчин и на 7,5\% у женщин.

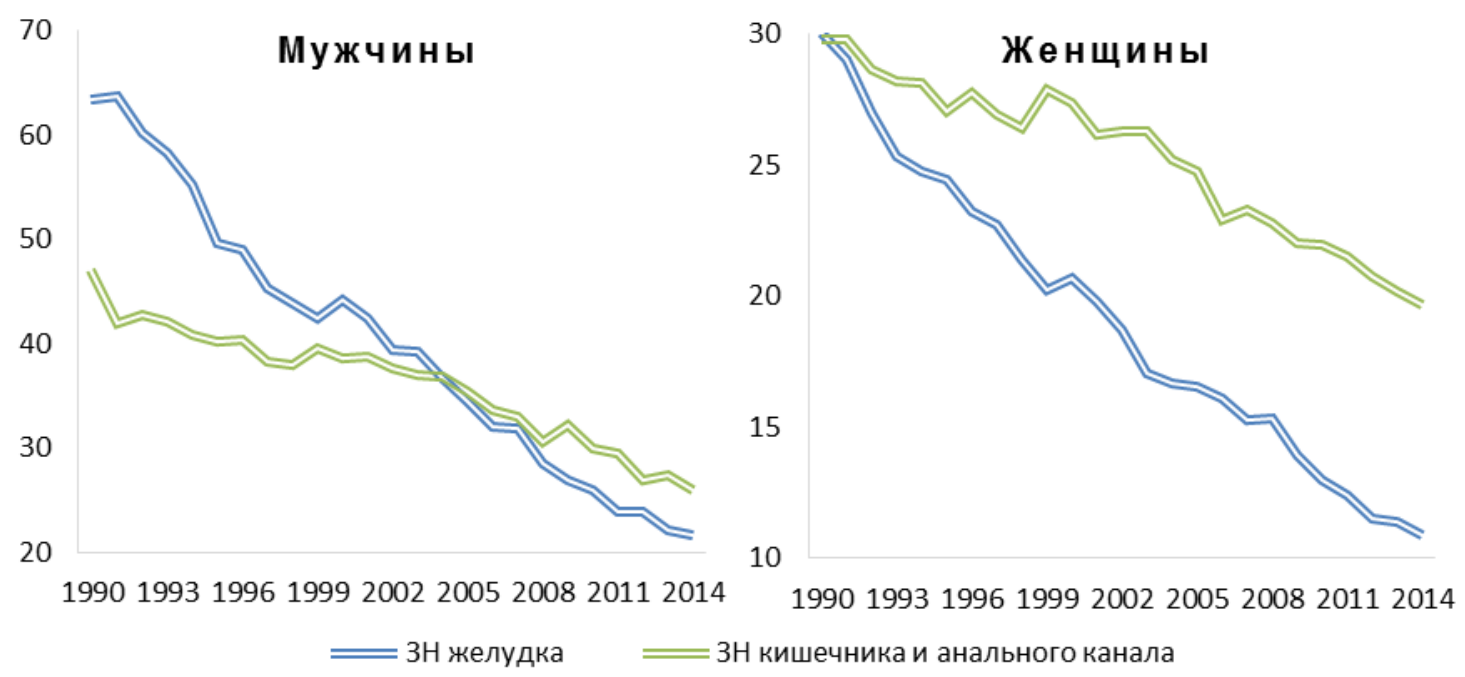

\section{Рисунок 11. Стандартизованные коэффициенты смертности от злокачественных новообразований органов пищеварения в Москве, 1990-2014, на 100000}

Рак желудка считается одной из прогностически неблагоприятных локализаций рака и характеризуется затрудненной ранней диагностикой. Так как период между постановкой диагноза и моментом смерти короток: медиана выживаемости больных в течение длительного времени в мире сохраняется на уровне 7 месяцев и для мужчин, и для женщин (без учета посмертно выявленных больных) и 5,7 месяцев с учетом посмертно выявленных больных [Мерабишвили 2013]. В Москве доля поставленных диагнозов с III-ей - IV-ой стадией рака выросла с 55\% в 2004 г. до 63\% в 2014 г.

По мнению специалистов, на величину показателя заболеваемости населения раком желудка оказывает влияние характер и режим питания. Наличие в рационе питания достаточного количества растительной пищи и фруктов, животных и растительных белков существенно снижает риск возникновения рака желудка. Наиболее наглядный пример США, где за последние 90 лет пропаганды рационального питания многократно снизилась заболеваемость населения раком желудка [Мерабишвили 2013].

Долгое время считалось, что эффективных программ скрининга рака желудка нет, так как отсутствует четко определенный специфический фактор этого заболевания. Но с конца 1980-х годов таким фактором стал считаться микроорганизм Helicobacter pylori (HP). Наличие у человека этого микроорганизма резко повышает вероятность его заболевания раком желудка [Wroblewski 2010]. К сожалению, такие анализы не включены в программы скрининга и диспансеризации.

Одним из критериев контроля качества онкологической помощи населению служит индекс достоверности учета ${ }^{6}$ [Каприн и др. 2015: 11], отражающий, с одной стороны,

\footnotetext{
6 Число больных, умерших в течение первого года после установления диагноза из взятых на учет в предыдущем году, к числу больных, у которых опухолевый процесс выявлен на IV стадии после установления диагноза из взятых на учет в предыдущем году.
} 
уровень учета заболеваемости, с другой - успехи в снижении смертности от конкретных локализаций. Так как рак желудка характеризуется довольно коротким периодом между постановкой диагноза и моментом смерти, то в отношении него индекс достоверности также отражает наличие недоучета больных данной локализацией (если индекс больше 1). В Москве (таблица 8) в последние 10 лет этот индекс колеблется около 1. В СанктПетербурге он значительно меньше.

Таблица 8. Индекс достоверности учета злокачественных новообразований желудка, 2004-2013

\begin{tabular}{l|c|c|c|c}
\hline \multirow{2}{*}{ Год } & \multicolumn{2}{|c|}{ Москва } & \multicolumn{2}{c}{ Санкт-Петербург } \\
\cline { 2 - 5 } & мужчины & женщины & мужчины & женщины \\
\hline 2004 & 1,01 & 0,94 & 0,86 & 0,86 \\
2005 & 0,92 & 0,91 & 0,86 & 0,86 \\
2006 & 0,94 & 0,98 & 0,86 & 0,86 \\
2007 & 0,98 & 0,96 & 0,86 & 0,86 \\
2008 & 0,86 & 0,92 & 0,86 & 0,86 \\
2009 & 0,85 & 0,88 & 0,86 & 0,86 \\
2010 & 0,92 & 0,89 & 0,86 & 0,86 \\
2011 & 0,95 & 1,01 & 0,86 & 0,86 \\
2012 & 0,99 & 1,03 & 0,86 & 0,86 \\
\hline
\end{tabular}

Источник: Расчеты авторов по данным Минздрава.

В отличие от смертности от рака желудка смертность от злокачественных новообразований кишечника и анального канала характеризуется очень медленным снижением (1,8 раза у мужчин и 1,5 раза у женщин; рисунок 11). Если в 1990 г. уровень смертности у мужчин от рака желудка был выше, чем от новообразований кишечника и анального канала, то к 2014 г. эти локализации поменялись местами: уровень смертности от рака кишечника и анального канала стал выше, чем желудка.

\section{Рак предстательной железы}

У мужчин третье место в структуре смертности от новообразований занимает рак предстательной железы (C61). Уровень смертности от рака предстательной железы в Москве и Санкт-Петербурге в течение всего периода остается намного выше, чем в рассматриваемых зарубежных мегаполисах, хотя в них (за исключением Лондона и ЛосАнджелеса) просматривается тенденция к некоторому увеличению показателя (таблица 9).

Таблица 9. Стандартизованные коэффициенты смертности от злокачественных новообразований предстательной железы в 7 мегаполисах, 1990, 2000, 2010, 2013, на 100000

\begin{tabular}{l|r|r|r|r}
\hline Мегаполис & $1990^{*}$ & 2000 & 2010 & $2013^{* *}$ \\
\hline Берлин & 5,0 & 6,9 & 7,5 & 7,6 \\
Гонконг & 5,0 & 6,9 & 7,5 & 7,6 \\
Лондон & 3,3 & 3,2 & 2,9 & 2,7 \\
Лос-Анджелес & н.Д & 20,0 & 17,1 & 14,1 \\
Москва & 17,1 & 17,6 & 19,6 & 17,8 \\
Санкт-Петербург & 14,8 & 18,3 & 21,4 & 22,1 \\
Сингапур & 8,0 & 11,4 & 8,7 & 11,3 \\
\hline
\end{tabular}

Примечания: *-Лос-Анджелес-1995 г., Нью-Йорк- 1997 г.; **-Лос-Анджелес - 2012 г. 
Динамика смертности от рака предстательной железы в Москве не такая, как от других локализаций: с начала 1990-х и до 2006 г. СКС рос, а затем началось медленное снижение (рисунок 12). В результате к 2014 г. уровень смертности от рака предстательной железы оказался выше, чем был в 1990 г. За период с 2004 по 2014 г. доля этой локализации рака, выявленной на III-IV стадиях, уменьшилась с 49 до $30 \%$.

Скрининг предстательной железы, как и рака молочной железы, начался в Москве с 2002-2004 гг. после Приказа Комитета здравоохранения г. Москвы №50 от 06.02.2002 "О реализации программы "Целевая диспансеризация населения Москвы на 2002-2004 гг." (Подпрограмма "Целевая диспансеризация мужского населения по выявлению заболеваний предстательной железы")". Дальше во всех программах диспансеризации населения выделялись похожие подпрограммы. В действующей в настоящее время в Москве Целевой программе развития здравоохранения «Столичное здравоохранение» выделяется подпрограмма «Целевая диспансеризация мужского населения по раннему выявлению заболевания предстательной железы». Но, судя по показателям смертности, эффективность этих программ не очень высока.

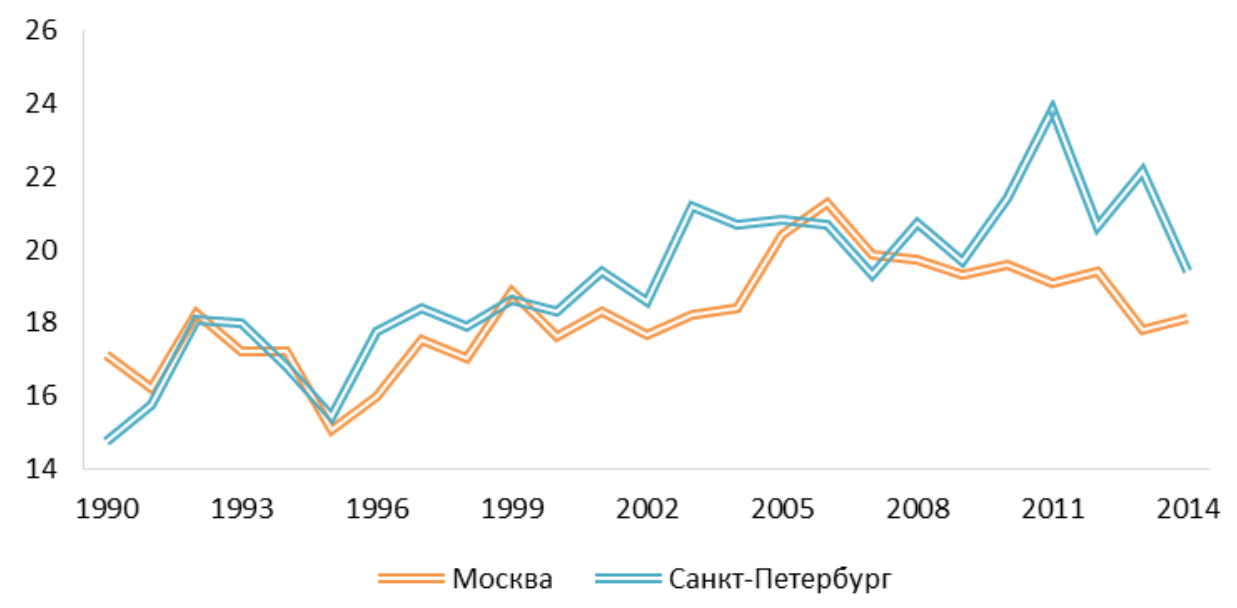

\section{Рисунок 12. Стандартизованные коэффициенты смертности от рака предстательной железы в Москве и Санкт-Петербурге, 1990-2014, на 100000}

В Санкт-Петербурге динамика смертности от рака предстательной железы до 2008 г. очень близка к московской. Отличие - в росте показателей в начале 2010-х годов. Ряд специалистов объясняют такие различия в уровнях смертности по регионам страны «возрастной структурой и степенью достоверности учета» [Мерабишвили и др. 2014], хотя не совсем понятно, как возрастная структура влияет на стандартизованные показатели.

\section{Внечние причины смерти}

Внешние причины занимают третье место в структуре смертности в Москве. На протяжении четверти века динамика СКС от этого класса причин для мужчин и женщин очень схожа при большом различии в уровне смертности. Рост СКС в 1990-1994 гг. связан в основном с прекращением антиалкогольной кампании, но также является прямым следствием глубокого экономического кризиса, охватившего все постсоветские страны [Shkolnikov et al. 2001, Андреев 2002]. 
«Зубец» 1998-2001 гг. наиболее вероятно связан с переходом России на 10-й пересмотр Международной классификации болезней (МКБ-10), который сопровождался передачей кодирования причин смерти от органов статистики врачам (в случае внешних причин - судмедэкспертам), устанавливающим причину смерти. Официально Россия перешла на МКБ-10 в 1999 г., но Москва реально это сделала только в 2000 г. [Данилова 2015]. В целом за 1990-2014 гг. уровень смертности от внешних причин в Москве снизился как у мужчин, так и у женщин в 2,1 раза (рисунок 13).
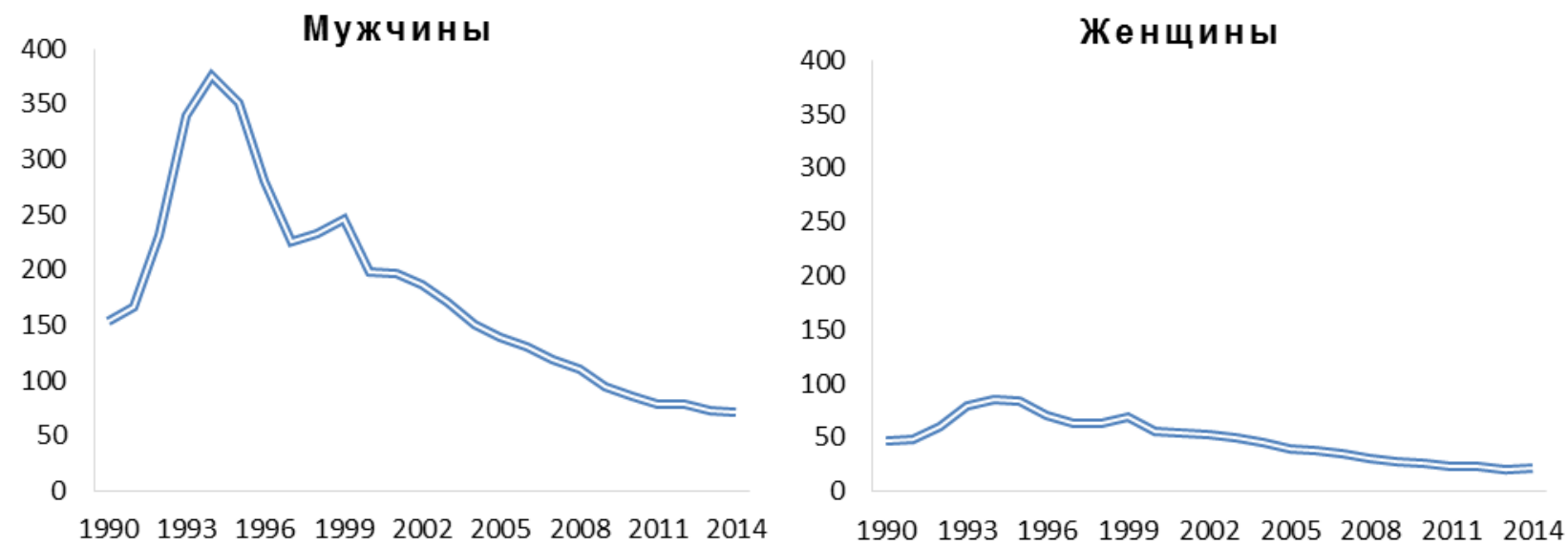

\section{Рисунок 13. Стандартизованные коэффициенты смертности от внешних причин смерти в Москве, 1990-2014, на 100000}

Тем не менее по уровню смертности от внешних причин Москва, как и СанктПетербург, значительно превосходили и превосходят зарубежные мегаполисы (рисунок 14), причем в 2000 г. у мужчин СКС был в 15 раз, а в 2013 - 8 раз выше минимального для этих мегаполисов уровня. У женщин разница соответственно в 8 и 4 раза.

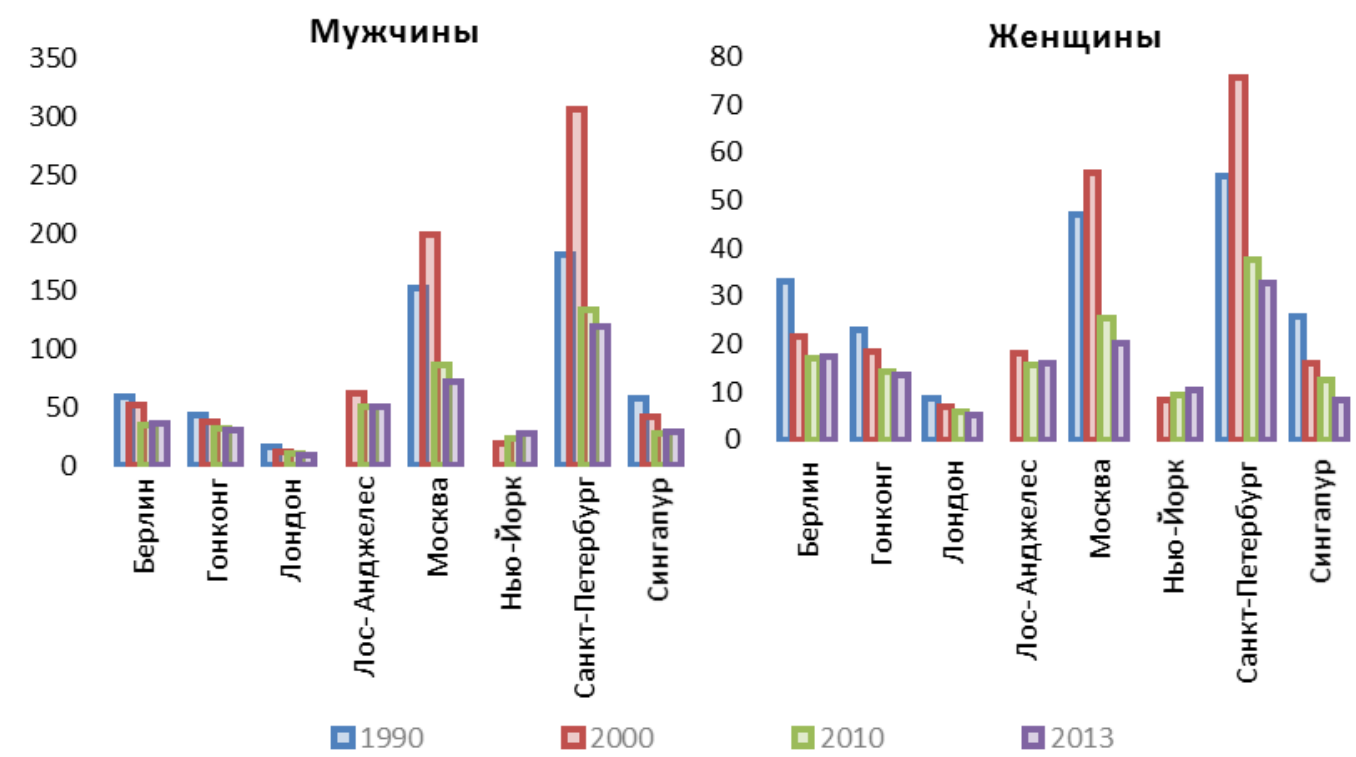

Рисунок 14. Стандартизованные коэффициенты смертности от внешних причин смерти в 8 мегаполисах, 1990, 2000, 2010, 2013, на 100000

Примечание: Лос-Анджелес - 2012 г. 
Структура смертности внутри класса внешних причин смерти в зарубежных мегаполисах сильно отличается от московской и санкт-петербургской (рисунок 15, таблица 10). Основной вклад в смертность от внешних причин во многих из них, как и в Москве, вносят другие внешние причины, но в целом попарные сравнения обнаруживают довольно пеструю картину.

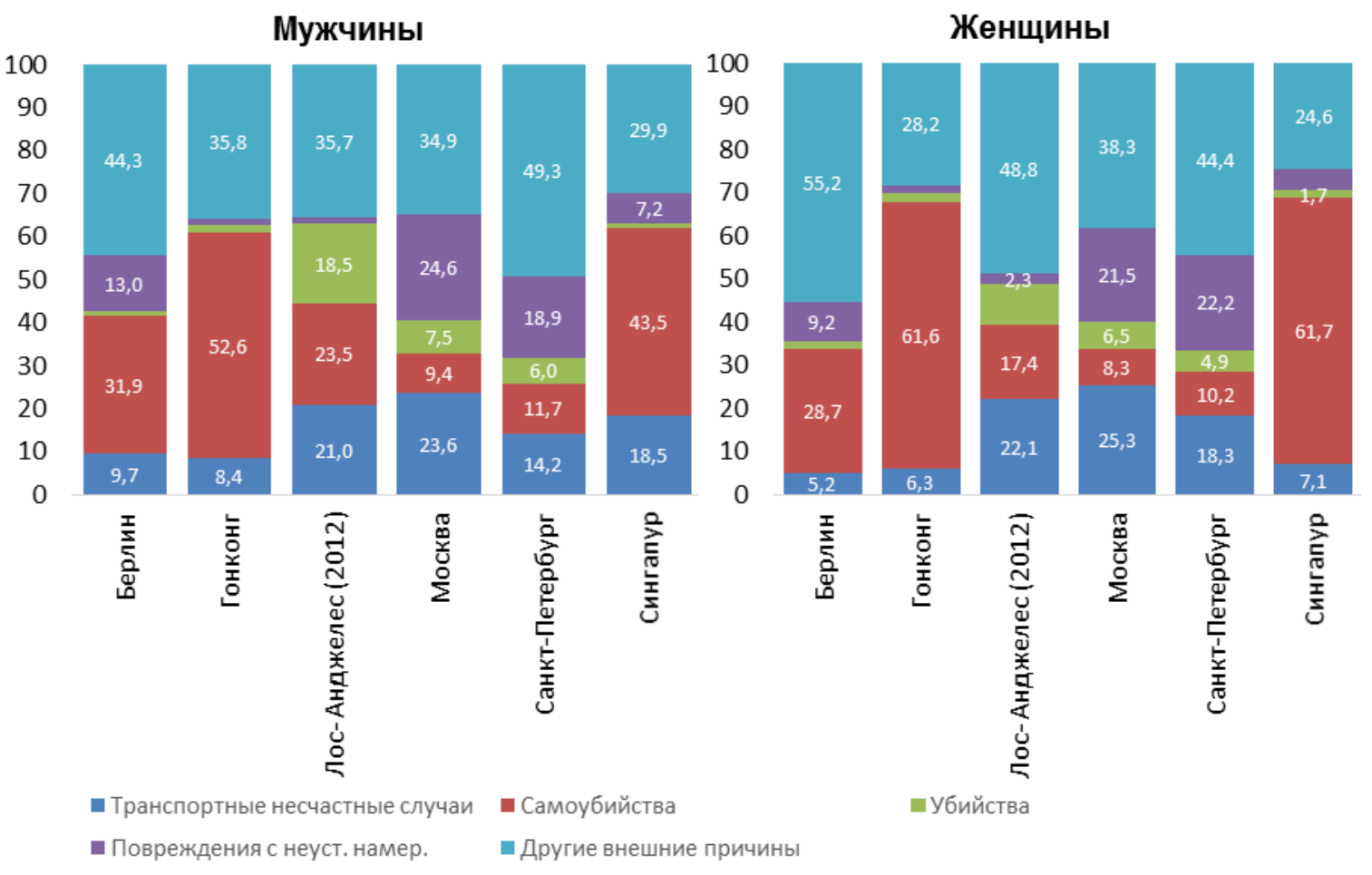

Рисунок 15. Структура стандартизованного коэффициента смертности от внешних причин смерти по группам причин в некоторых мегаполисах, 2013, \%

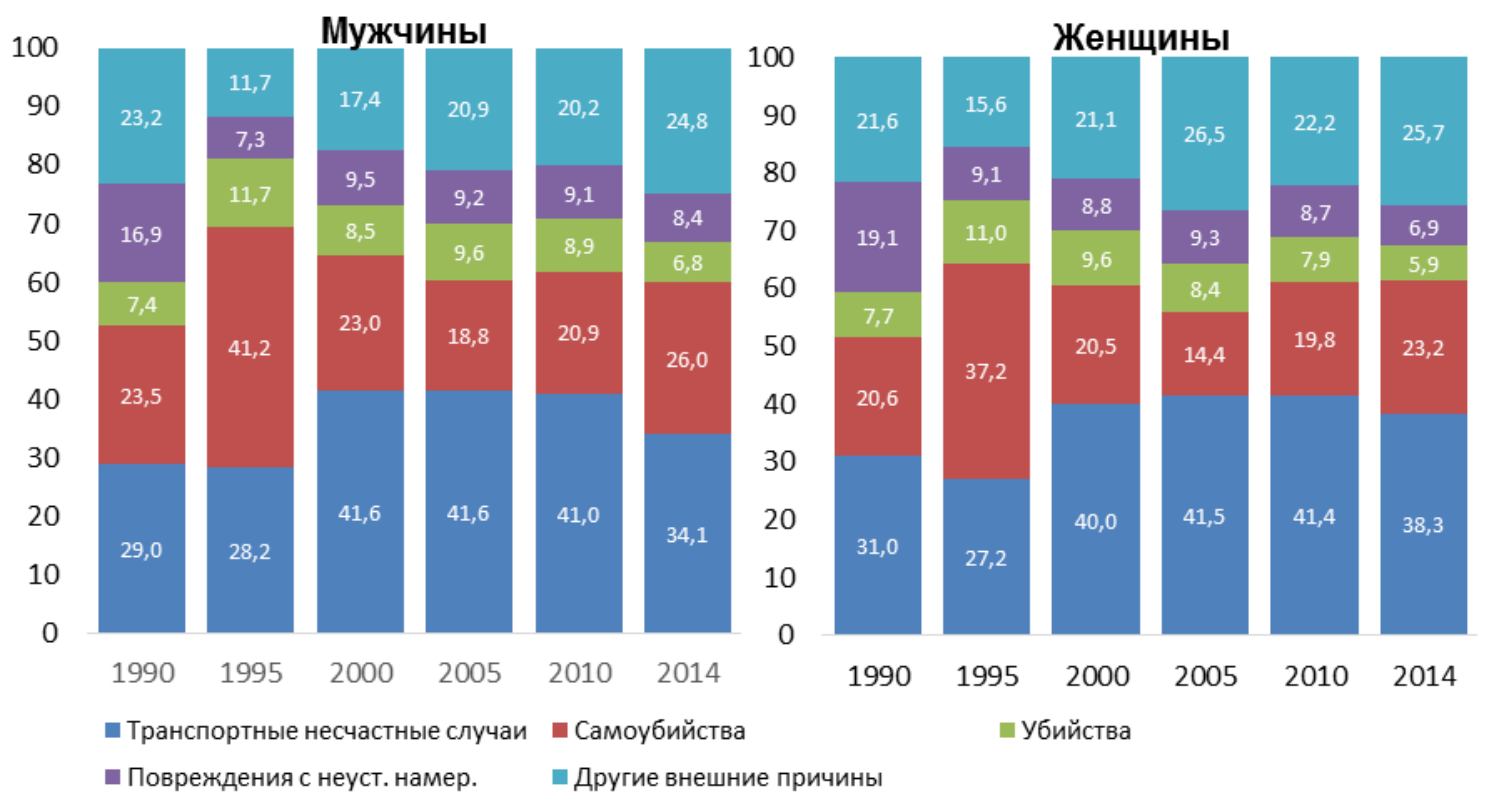

Рисунок 16. Структура стандартизованного коэффициента смертности от внешних причин в Москве, 1990-2014, \% 
Москва и Петербург явно превосходят другие мегаполисы по смертности от транспортных несчастных случаев, но находятся далеко не на самых худших местах по смертности от самоубийств и убийств.

Таблица 10. Стандартизованные коэффициенты смертности от транспортных несчастных случаев, убийств и самоубийств в 8 мегаполисах, 1990, 2000, 2010, 2013, на 100000

\begin{tabular}{|c|c|c|c|c|c|c|c|c|}
\hline \multirow[b]{2}{*}{ Мегаполис } & \multicolumn{4}{|c|}{ Мужчины } & \multicolumn{4}{|c|}{ Женщины } \\
\hline & 1990* & 2000 & 2010 & $2013 * *$ & $1990^{*}$ & 2000 & 2010 & $2013 * *$ \\
\hline \multicolumn{9}{|c|}{ Транспортные несчастные случаи } \\
\hline Берлин & 13,7 & 7,1 & 2,7 & 3,5 & 5,2 & 3,0 & 2,2 & 0,9 \\
\hline Гонконг & 9,1 & 3,9 & 2,9 & 2,6 & 5,1 & 1,9 & 0,9 & 0,8 \\
\hline Лондон & 6,6 & 4,5 & 3,3 & 2,8 & 1,9 & 1,3 & 1,0 & 0,8 \\
\hline Лос-Анджелес & 17,5 & 13,4 & 9,0 & 10,9 & 6,8 & 5,6 & 3,8 & 3,3 \\
\hline Москва & 35,5 & 34,5 & 17,3 & 17,0 & 10,1 & 11,7 & 5,7 & 5,1 \\
\hline Нью-Йорк & 10,1 & 6,8 & 4,8 & 5,1 & 4,3 & 3,2 & 1,9 & 2,0 \\
\hline Санкт-Петербург & 33,7 & 38,5 & 16,9 & 17,0 & 10,9 & 13,4 & 6,4 & 6,0 \\
\hline Сингапур & 16,5 & 10,0 & 6,4 & 5,3 & 4,7 & 2,1 & 2,1 & 0,6 \\
\hline \multicolumn{9}{|c|}{ Самоубийства } \\
\hline Берлин & 20,4 & 18,5 & 13,6 & 11,5 & 9,9 & 6,7 & 4,6 & 5,0 \\
\hline Гонконг & 15,0 & 16,1 & 16,5 & 15,9 & 10,8 & 10,0 & 8,4 & 8,3 \\
\hline Лондон & 6,0 & 4,2 & 2,9 & 2,5 & 4,2 & 2,8 & 1,8 & 1,5 \\
\hline Лос-Анджелес & 18,6 & 12,7 & 12,5 & 11,9 & 3,8 & 3,0 & 2,9 & 2,1 \\
\hline Москва & 25,8 & 18,7 & 7,8 & 6,7 & 8,9 & 4,9 & 2,2 & 1,7 \\
\hline Нью-Йорк & 10,5 & 8,6 & 8,7 & 8,9 & 3,5 & 2,2 & 2,6 & 3,0 \\
\hline Санкт-Петербург & 30,8 & 29,0 & 16,6 & 14,0 & 8,5 & 7,0 & 3,7 & 3,3 \\
\hline Сингапур & 17,8 & 13,7 & 10,4 & 12,5 & 12,6 & 6,6 & 4,9 & 5,2 \\
\hline Токио & 17,4 & 28,1 & 25,5 & 22,6 & 9,8 & 11,4 & 11,4 & 11,1 \\
\hline \multicolumn{9}{|c|}{ Убийства } \\
\hline Берлин & 1,9 & 1,1 & 0,4 & 0,4 & 1,5 & 0,8 & 0,4 & 0,3 \\
\hline Гонконг & 2,6 & 0,9 & 0,5 & 0,5 & 1,3 & 0,9 & 0,6 & 0,3 \\
\hline Лос-Анджелес & 18,2 & 16,5 & 9,9 & 9,7 & 4,9 & 2,9 & 1,9 & 1,4 \\
\hline Москва & 11,3 & 16,9 & 7,6 & 5,4 & 3,6 & 5,3 & 2,0 & 1,3 \\
\hline Нью-Йорк & 17,3 & 14,5 & 10,5 & 6,5 & 3,4 & 2,7 & 2,0 & 1,3 \\
\hline Санкт-Петербург & 12,2 & 29,3 & 11,1 & 7,1 & 4,2 & 9,0 & 3,3 & 1,6 \\
\hline Сингапур & 1,7 & 1,6 & 0,6 & 0,3 & 1,1 & 0,6 & 0,1 & 0,1 \\
\hline
\end{tabular}

Примечания: *-Лос-Анджелес-1995 г., Нью-Йорк- 1997 г.; **-Лос-Анджелес - 2012 г.

Структура смертности от внешних причин в Москве менялась со временем. Но главное оставалось неизменным: основной вклад вносят две группы причин «Повреждения с неустановленными намерениями» (ПНН) и собирательная группа «Другие внешние причины» (рисунок 16).

На третьем месте в Москве находятся транспортные несчастные случаи, на долю которых во внешних причинах в 2014 г. приходилось 24,8\% у мужчин и 25,7\% у женщин. Основная часть смертей в результате транспортных несчастных случаев в Москве и в других мегаполисах связана с дорожно-транспортными происшествиями. За 25 лет смертность от транспортных несчастных случаев снизилась в 2 раза у мужчин и в 1,8 раза у женщин (рисунок 17). Это снижение происходило волнообразно. Первая волна закончилась минимумом 1998 г., после чего последовал новый подъем и новый спад. В 2007 г. был достигнут уровень 1998 г., после чего снижение продолжалось до начала 2010-х годов, когда наметилась стабилизация показателей. Тенденции смертности от ДТП в Москве мало отличаются от общероссийских [Фаттахов 2015]. 
Несмотря на снижение, уровень смертности от транспортных несчастных случаев в Москве и Санкт-Петербурге намного выше, чем в зарубежных мегаполисах (таблица 9), где смертность от этой причины снижается значительно быстрее, чем в двух российских столицах, в результате чего отрыв Москвы и Санкт-Петербурга от других рассматриваемых мегаполисов за четверть века вырос.

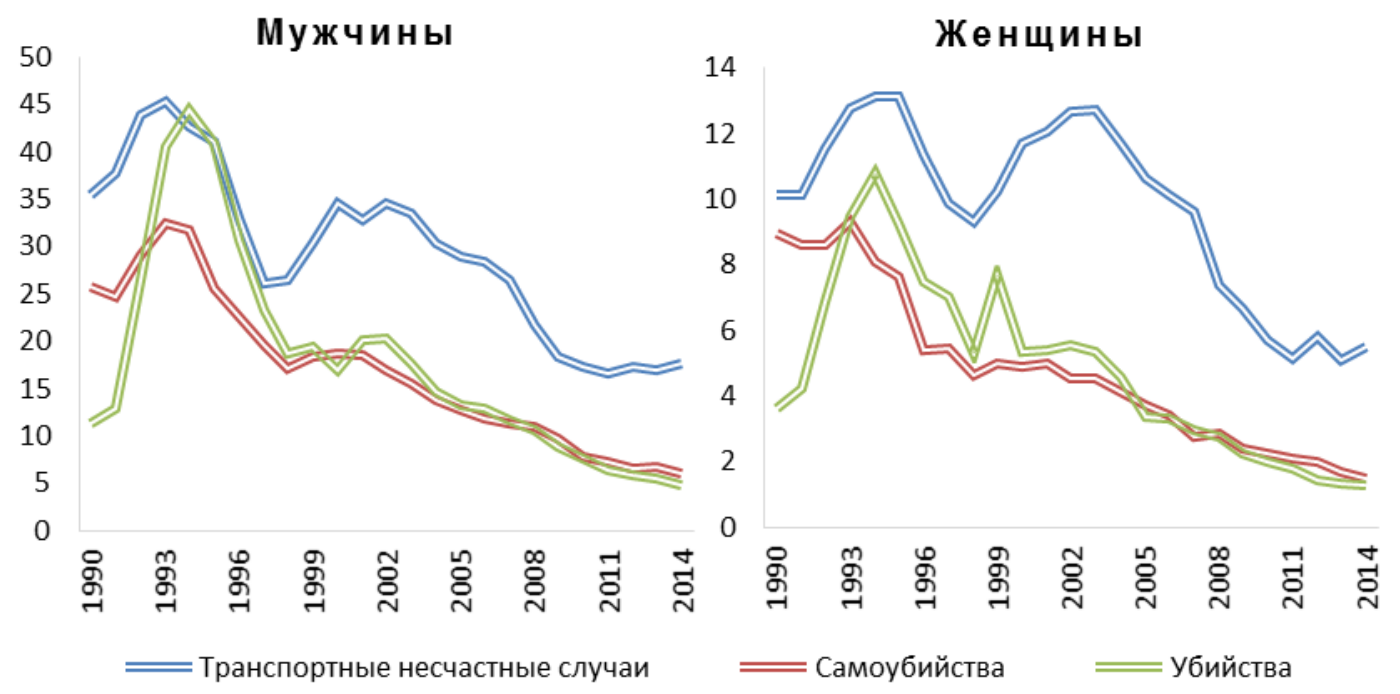

\section{Рисунок 17. Стандартизованные коэффициенты смертности от транспортных несчастных случаев, убийств и самоубийств в Москве, 1990-2014, на 100000}

В России в целом и во многих регионах принимаются программы, направленные на снижение смертности от ряда причин. Часть (и не малая) из этих программ связана со снижением смертности от дорожно-транспортных происшествий. Так, для претворения в жизнь мер первого этапа Концепции демографической политики Российской Федерации на период до 2025 г. (2007-2010 гг.) распоряжением Правительства Российской Федерации №170-р от 14 февраля 2008 г. утвержден план мероприятий на 2008-2010 гг., включающий комплекс мер по профилактике, диагностике, лечению сердечно-сосудистых заболеваний; по обеспечению оказания своевременной и высококачественной медицинской помощи при дорожно-транспортных происшествиях. За последние годы изменились правила безопасности на дорогах. В конце 2013 г. Д.А. Медведев подписал Постановление Правительства Российской Федерации от 3 октября 2013 г. № 864 г. «О федеральной целевой программе «Повышение безопасности дорожного движения в 2013 - 2020 годах» 7 , которая входит в список приоритетных Федеральных целевых программ на 2015 г.

В качестве результата этой программы декларируется «сокращение случаев смерти в результате дорожно-транспортных происшествий, в том числе детей, к 2020 году на 8 тыс. человек (28,82 процента) по сравнению с 2012 годом» ${ }^{8}$. Но, судя по динамике показателей смертности от транспортных несчастных случаев, в Москве эти программы в последние годы не дают видимых результатов.

\footnotetext{
${ }^{7}$ http://www.rg.ru/2013/10/08/bezopas-site-dok.html

${ }^{8} \mathrm{http}: / /$ fcp.economy.gov.ru/cgi-bin/cis/fcp.cgi/Fcp/ViewFcp/View/2015/409/
} 
Следующая по вкладу в общую смертность причина смерти, входящая в класс внешних причин, - это самоубийства. В Москве на долю этой причины в 2014 г. приходилось 8,4\% всех умерших от внешних причин смерти у мужчин и 6,9\% - у женщин. За 25 лет СКС от самоубийств в Москве снизился в 4,3 раза у мужчин и 6,1 раза у женщин. Снижение началось после подъема СКС в начале 1990-х годов и шло равномерно до конца периода. Пожалуй, это самые высокие темпы снижения за рассматриваемые годы. Правда, по мнению специалистов, число умерших в результате самоубийства в России недоучитывается. Часть смертей от них относится к другим причинам, но еще чаще включается в повреждения с неустановленными намерениями, по оценкам, в России к ним относят около 20\% всех самоубийств [Andreev et al. 2015]. Анализ свидетельств о смерти мужчин и женщин Москвы, умерших от травм и отравлений в трудоспособных возрастах, также показал, что Москва не является исключением [Семенова, Антонова 2007]. Впрочем, это явление - не специфическая российская, а мировая проблема [Васин 2015].

Возможно, именно из-за существенного недоучета смертность от самоубийств в Москве и Санкт-Петербурге часто ниже, чем в зарубежных мегаполисах, при том что доля смертей и стандартизованный коэффициент смертности от ПНН и в Москве существенно выше (рисунок 15 и 16, таблица 9).

К сожалению, в отличие от ДТП, программ, направленных на снижение смертности от самоубийств, в России нет. Перспективы Москвы с этой точки зрения выглядят лучше согласно Государственной программе города Москвы 2012-2016 гг. «Развитие здравоохранения в городе Москве (Столичное здравоохранение)» к концу 2016 г. в поликлиниках и психоневрологических диспансерах должны быть открыты суицидологические кабинеты.

Так же, как число самоубийств недоучитывается и число умерших в результате убийств. Часть убийств, вероятно, классифицируется как несчастные случаи, но еще чаще убийства кодируются как повреждения с неустановленными намерениями, по оценкам, к ним относится, примерно, 35-40\% всех убийств в России [Andreev et al. 2015].

Согласно официальным данным, за период с 1990 по 2014 г. уровень смертности от убийств в Москве, пройдя период подъема, снизился в 2,3 раза у мужчин и в 2,8 раза у женщин (рисунок 18). После скачка смертности от убийств в начале 1990-х годов дальнейшее снижение было почти линейным. По уровню смертности от убийств Москва уступает Лос-Анджелесу и Нью-Йорку, но существенно обгоняет остальные зарубежные мегаполисы. В странах ЕC-15 уровень смертности мужчин в результате убийств почти в 9 раз, а женщин - в 5,5 раза ниже, чем в Москве.

Почти четверть мужских смертей мужчин в результате внешних причин и более $21 \%$ женских классифицированы как повреждения с неустановленными намерениями. Согласно принципам МКБ-10 к этой группе относят случаи, когда доступной информации недостаточно, чтобы эксперты могли сделать вывод, является ли происшедшее событие несчастным случаем, самоповреждением или результатом насилия. Главная трудность в том, чтобы правильно оценить имеющуюся информацию. Проведенный С.А. Васиным анализ публикаций по данной теме показал, что в силу различных причин во всех развитых странах в число ПНН попадают и случаи, когда имеющихся данных достаточно, чтобы 
отнести их к самоубийствам или несчастным случаям [Васин 2015: 91-92]. В России, где смертность от убийств и так высока, в число ПНН попадают и убийства [Иванова и др. 2013].

Доля смертей от ПНН в Москве существенно выше, чем во всех зарубежных мегаполисах, а СКС, рассчитанный для совокупности смертей, классифицированных как ПНН, примерно втрое выше. Сравнив со странами ЕС-15, мы получили, что СКС, рассчитанный для совокупности смертей, классифицированных как ПНН, в Москве у мужчин в 9 раз, а у женщин в 6 раз выше. Возможно, это связано с тем, что в получении данных о смертности в Москве практически не участвуют повторные медицинские свидетельства о смерти «взамен предварительного» и «взамен окончательного» [Андреев 2016], которые как раз и призваны уточнять первоначально установленную причину смерти.

В Москве СКС с диагнозом ПНН сильно вырос в начале 1990-х годов, затем в середине 1990-х годов началось его медленное и непоследовательное снижение. В начале 2000-х годов одновременно с переходом на МКБ-10 и передачей кодирования причин смерти врачам, установившим причину смерти, доля ПНН в российской смертности резко снизилась, зато резко и необъяснимо выросла доля умерших при неустановленной причине смерти [Иванова и др. 2013]. С.А. Васин показал, что если суммировать ПНН и все неустановленные причины смерти, кроме причины «старость», то окажется, что смертность от такой группы в Москве практически не отреагировала на переход к МКБ-10 [Васин 2015: 103-104].

Мы провели аналогичный расчет для Москвы, взяв ПНН и целиком класс МКБ «Симптомы, признаки, отклонения от нормы, выявленные при клинических и лабораторных исследованиях, не классифицированные в других рубриках» (далее: неточно обозначенные причины; рисунок 18). Сумма ПНН и неточно обозначенных причин у мужчин с 2000 г. по 2008 г. вообще не проявляет тенденции к снижению, затем немного снижается, но после 2008 г. число смертей с неточно обозначенными причинами вновь возрастает.

Группа, названная «другие внешние причины смерти», - это, в основном, нетранспортные несчастные случаи. По оценкам, число умерших от нетранспортных несчастных случаев в России занижено на $15-20 \%$ в результате классификации их как ПНН [Andreev et al. 2015].

Смертность от других внешних причин в Москве у мужчин более чем вдвое, а у женщин в 1,6 раза ниже, чем в Санкт-Петербурге. По уровню у женщин она примерно, такая же, как и в зарубежных мегаполисах, у мужчин - в 1,4-3 раза выше. Но по ее вкладу в общую смертность от внешних причин Москва не выделяется из общего ряда ни для мужчин, ни для женщин (рисунок 15 и 16). 


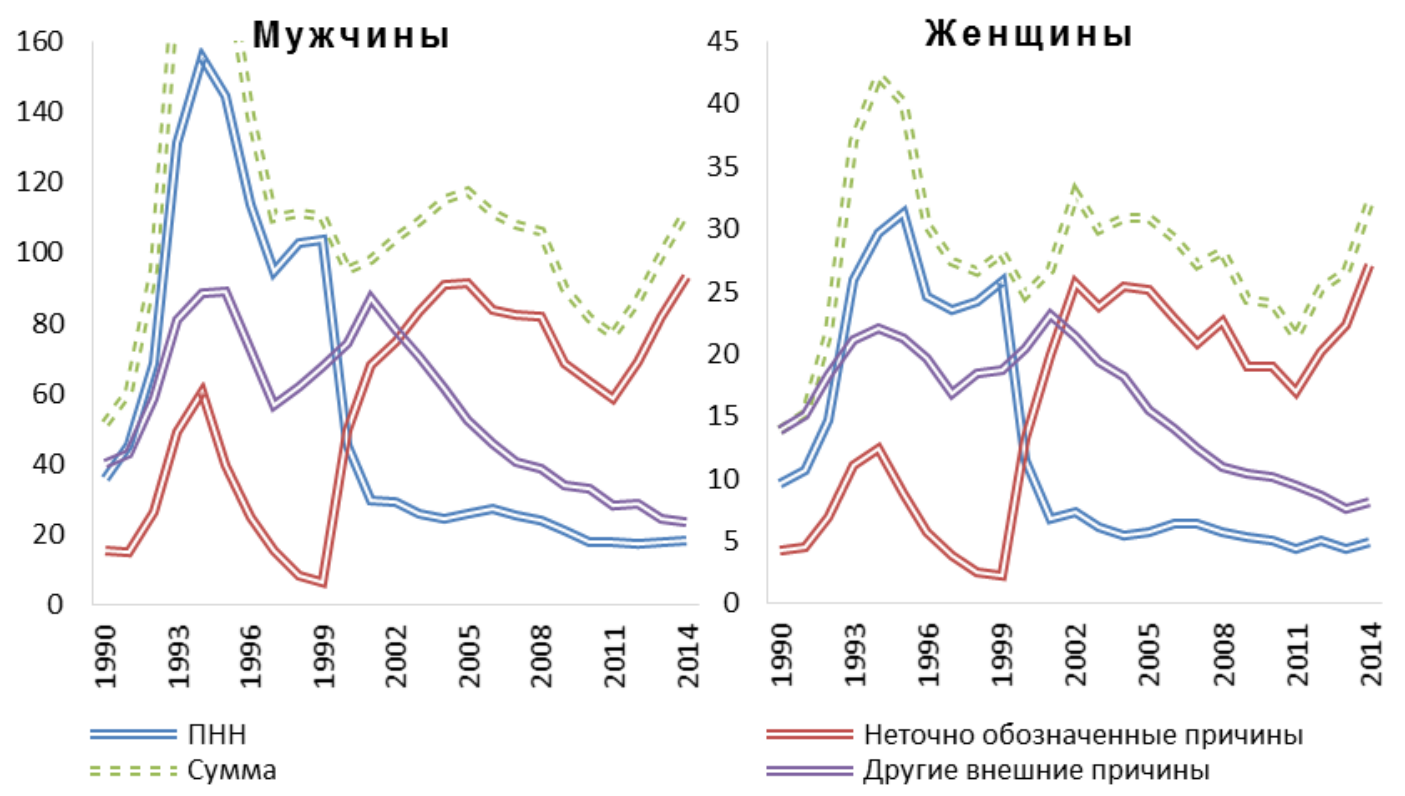

Рисунок 18. Стандартизованные коэффициенты смертности от повреждений с неопределенными намерениями, неточно обозначенных причин и "других внешних причин" в Москве, 1990-2014, на 100000

Примечание: ПНН - повреждения с неопределенными намерениями.

После 2000 г. и в Москве, и в зарубежных мегаполисах среди других внешних причин наиболее распространены случайные падения (довольно заметная причина в структуре причин смерти лиц пожилого возраста).

В Москве практически не регистрируется такая важная в России причина смерти, как случайные отравления алкоголем [Андреев 2016], что несомненно искажает реальную структуру смертности от внешних причин.

\section{Болезни органов дыхания}

Болезни органов дыхания занимают четвертое место в структуре причин смерти населения Москвы (рисунок 24), тогда как в зарубежных мегаполисах этим причинам принадлежит третье место.

Стандартизованный коэффициент смертности от болезней органов дыхания в Москве и Санкт-Петербурге был и остается ниже, чем в других мегаполисах (рисунок 19), что само по себе не является преимуществом, потому что средний возраст смерти от этой причины у нас довольно низкий, тогда как в развитых странах он часто выше, чем от болезней системы кровообращения. 


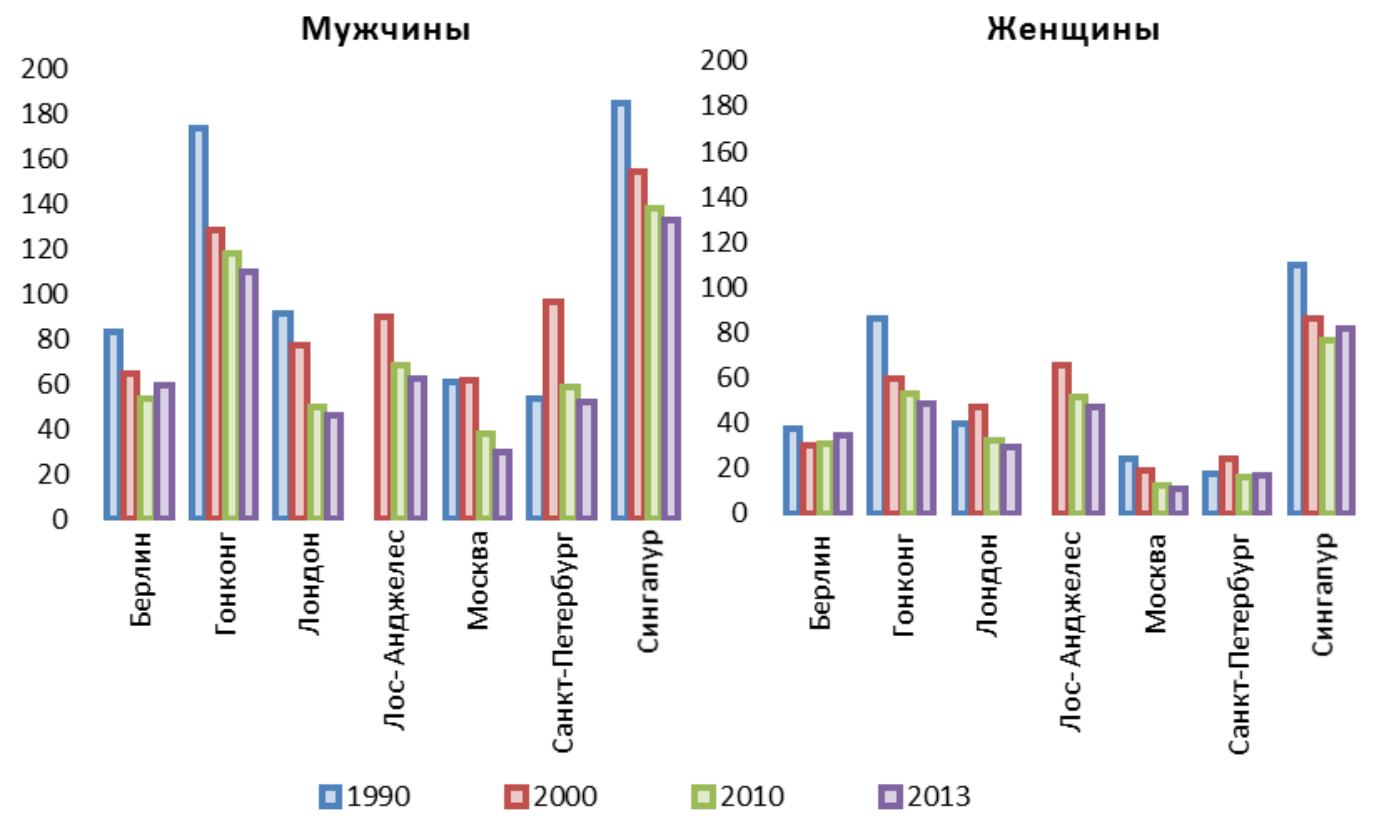

\section{Рисунок 19. Стандартизованные коэффициенты смертности от болезней органов дыхания в 7 мегаполисах, 1990, 2000, 2010, 2013, на 100000}

Примечание: Лос-Анджелес - 2012 г.

Основной вклад в смертность от болезней органов дыхания до середины 2000-х вносили умершие от пневмонии и бронхита. После 2005 г. в Москве удалось снизить смертность от бронхита до минимума, но на пневмонию сейчас приходится почти $60 \%$ всех смертей от болезней органов дыхания. С 1990 по 2014 г. СКС от болезней органов дыхания снизился в Москве в 2,1 раза у мужчин и в 2,5 раза у женщин (рисунок 20). В его динамике выделяются те же периоды, что и в динамике СКС от болезней системы кровообращения и большинства внешних причин: подъем в начале 1990-х годов с максимумом в 1994 г., последующее снижение с минимумом в 1998 г., новый подъем, который после 2003 г. переходит в последовательное снижение. Варьируется лишь последняя точка максимума: у мужчин это 2001 г., у женщин - 2002 г.

Смерти от пневмонии во всех рассмотренных мегаполисах составляют не менее $35 \%$ всех умерших от болезней органов дыхания. В Сингапуре доля пневмонии составляет 74\% у мужчин и 91\% у женщин, а на умерших от болезней органов дыхания приходится более 20\% всех умерших. Статистика Нью-Йорка вообще не содержит данных по всему классу болезней органов дыхания. Есть данные только по пневмонии и хронической обструктивной болезни легких. По сравнению с этими мегаполисами уровень смертности от пневмонии в Москве самый низкий (таблица 11), но нельзя не учитывать, что сегодня в развитых странах от пневмонии умирают в основном люди пожилого (можно сказать, очень пожилого) возраста, у которых на момент смерти почти всегда имеется не одно заболевание. Какая причина будет указана в свидетельстве о смерти в качестве основной и соответственно попадет в статистику, во многом зависит от правил выбора основной причины смерти, сложившихся в стране и регионе. 


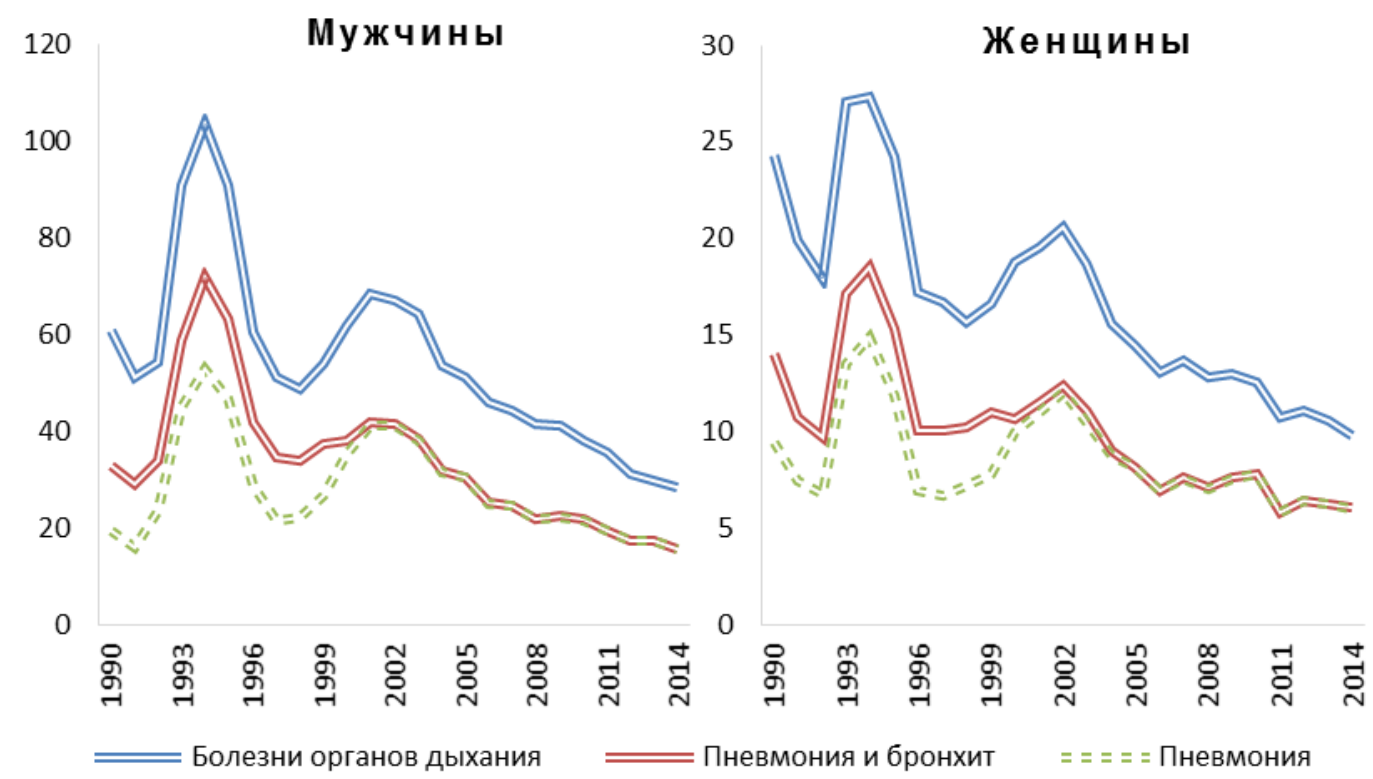

Рисунок 20. Стандартизованные коэффициенты смертности от болезней органов дыхания в Москве, 1990-2014, на 100000

Таблица 11. Стандартизованные коэффициенты смертности от пневмонии в 8 мегаполисах, 1990, 2000, 2010, 2013, на 100000

\begin{tabular}{l|r|r|r|r|r|r|r|r}
\hline \multirow{2}{*}{ Мегаполис } & \multicolumn{4}{|c|}{ Мужчины } & \multicolumn{4}{c}{ Женщины } \\
\cline { 2 - 9 } & $1990^{*}$ & 2000 & 2010 & $2013^{* *}$ & $1990^{*}$ & 2000 & 2010 & $2013^{* *}$ \\
\hline Берлин & 24,8 & 22,2 & 20,8 & 20,6 & 13,8 & 10,4 & 10,7 & 11,3 \\
Гонконг & 69,6 & 63,4 & 73,3 & 75,3 & 36,5 & 37,5 & 39,3 & 38,7 \\
Лос-Анджелес & н.Д & 39,1 & 27,8 & 26,9 & н.д & 33,6 & 22,9 & 21,2 \\
Москва & 19,5 & 35,4 & 21,5 & 17,2 & 9,4 & 10,0 & 7,8 & 6,2 \\
Нью-Йорк & 35,8 & 29,6 & 28,9 & 28,4 & 23,8 & 19,8 & 19,8 & 17,7 \\
Санкт-Петербург & 16,8 & 59,3 & 34,2 & 31,4 & 6,9 & 14,7 & 9,4 & 10,6 \\
Сингапур & 92,9 & 102,2 & 106,2 & 111,0 & 72,9 & 68,6 & 66,2 & 73,8 \\
Токио*** & 84,6 & 58,0 & 46,8 & 43,8 & 40,4 & 28,7 & 22,1 & 19,9 \\
\hline
\end{tabular}

Примечания: *-Нью-Йорк- 1997 г.; **-Лос-Анджелес- 2012 г.; ***-пневмония и бронхит.

\section{Болезни органов пищеварения}

От болезней органов пищеварения в Москве в 2014 г. умерло 4,3\% всех умерших мужчин и 4,2\% женщин. За 25 лет вклад этого класса причин смерти в СКС вырос на 1 процентный пункт у мужчин и 1,3 процентных пункта у женщин. Уровень смертности от болезней органов пищеварения с 1990 по 2014 г. снизился в 1,3 раза у мужчин и в 1,2 раза у женщин, причем реальное снижение уровня смертности от этого класса началось только в 2008 г. (рисунок 21). В Санкт-Петербурге доля этого класса не отличается от московской, а уровень смертности немного выше. В Берлине смертность от болезней органов пищеварения немного ниже, чем в российских мегаполисах. В других же мегаполисах от этого класса причин смерти умирает в 2-4 раза меньше людей (таблица 12). 


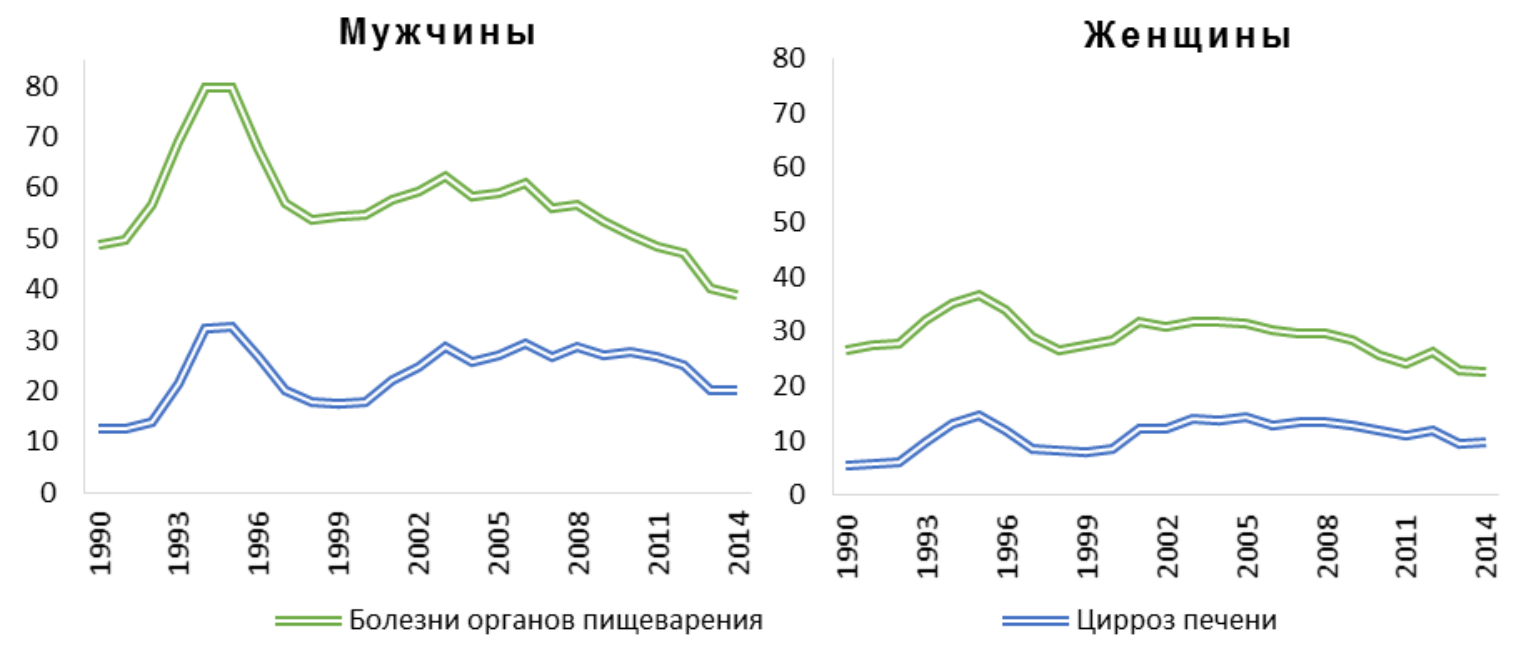

Рисунок 21. Стандартизованные коэффициенты смертности от болезней органов пищеварения и цирроза печени в Москве, 1990-2014, на 100000

Основной вклад в смертность от болезней органов пищеварения вносят циррозы печени, динамика смертности от них определяла и динамику всего класса. За период с 1990 по 2014 г. СКС от цирроза печени в Москве вырос на 40\% и у мужчин, и у женщин. За счет этого вклад цирроза за 25 лет вырос с 26 до 52\% у мужчин и с 21 до 43\% у женщин. Уровень смертности от цирроза печени в Москве и Санкт-Петербурге в разы превышает смертность в зарубежных мегаполисах.

Таблица 12. Стандартизованные коэффициенты смертности от болезней органов пищеварения и цирроза печени в 7 мегаполисах, 1990, 2000, 2010, 2013, на 100000

\begin{tabular}{|c|c|c|c|c|c|c|c|c|}
\hline \multirow{2}{*}{ Мегаполис } & \multicolumn{4}{|c|}{ Мужчины } & \multicolumn{4}{|c|}{ Женщины } \\
\hline & $1990 *$ & 2000 & 2010 & $2013 * *$ & $1990^{*}$ & 2000 & 2010 & $2013 * *$ \\
\hline \multicolumn{9}{|c|}{ Болезни органов пищееварения } \\
\hline Берлин & 59,6 & 47,0 & 36,7 & 36,8 & 36,4 & 28,0 & 25,1 & 20,3 \\
\hline Гонконг & 36,3 & 28,5 & 20,9 & 16,6 & 20,6 & 17,5 & 10,9 & 9,3 \\
\hline Лондон & 9,4 & 13,5 & 12,6 & 10,4 & 4,9 & 5,9 & 5,3 & 4,6 \\
\hline Лос-Анджелес & н.д & 31,9 & 25,4 & 26,6 & н.Д & 18,4 & 14,1 & 14,1 \\
\hline Москва & 48,8 & 54,7 & 50,6 & 40,3 & 26,7 & 28,5 & 25,7 & 22,8 \\
\hline Санкт-Петербург & 46,6 & 59,5 & 61,3 & 48,7 & 27,1 & 31,8 & 30,7 & 25,3 \\
\hline Сингапур & 30,5 & 15,0 & 13,4 & 11,4 & 14,9 & 10,6 & 9,9 & 8,2 \\
\hline \multicolumn{9}{|c|}{ Цирроз печени } \\
\hline Гонконг & 10,3 & 10,5 & 4,4 & 3,4 & 4,2 & 5,0 & 2,1 & 1,5 \\
\hline Лондон & 8,8 & 13,0 & 12,1 & 10,1 & 4,8 & 5,8 & 5,2 & 4,5 \\
\hline Лос-Анджелес & н.д & 4,7 & 2,7 & 3,3 & н.Д & 3,6 & 3,2 & 3,8 \\
\hline Москва & 12,5 & 17,8 & 27,8 & 20,1 & 5,5 & 8,6 & 11,9 & 9,5 \\
\hline Нью-Йорк & 17,3 & 12,0 & 9,1 & 9,4 & 5,1 & 3,6 & 3,4 & 3,5 \\
\hline Санкт-Петербург & 11,7 & 15,4 & 27,4 & 21,6 & 4,8 & 8,9 & 12,7 & 9,6 \\
\hline Сингапур & 11,6 & 5,3 & 4,3 & 3,0 & 3,5 & 2,8 & 2,4 & 2,2 \\
\hline
\end{tabular}

Примечания: *-Нью-Йорк- 1997 г.; **-Лос-Анджелес - 2012 г.

\section{Инфекционные и паразитарные болезни}

Вклад инфекционных и паразитарных болезней в стандартизованный коэффициент смертности от всех причин в Москве в 2014 г. составил 1,7\% для мужчин и 1,1\% для женщин. В 1990 г. эти доли были еще меньше - соответственно 1,1 и 0,5\%. С 1990 г. СКС от инфекционных и паразитарных болезней у мужчин почти не изменился, а у женщин 
вырос, рост (хотя и медленными темпами и скачкообразно) идет с начала 2000-х годов (рисунок 22).

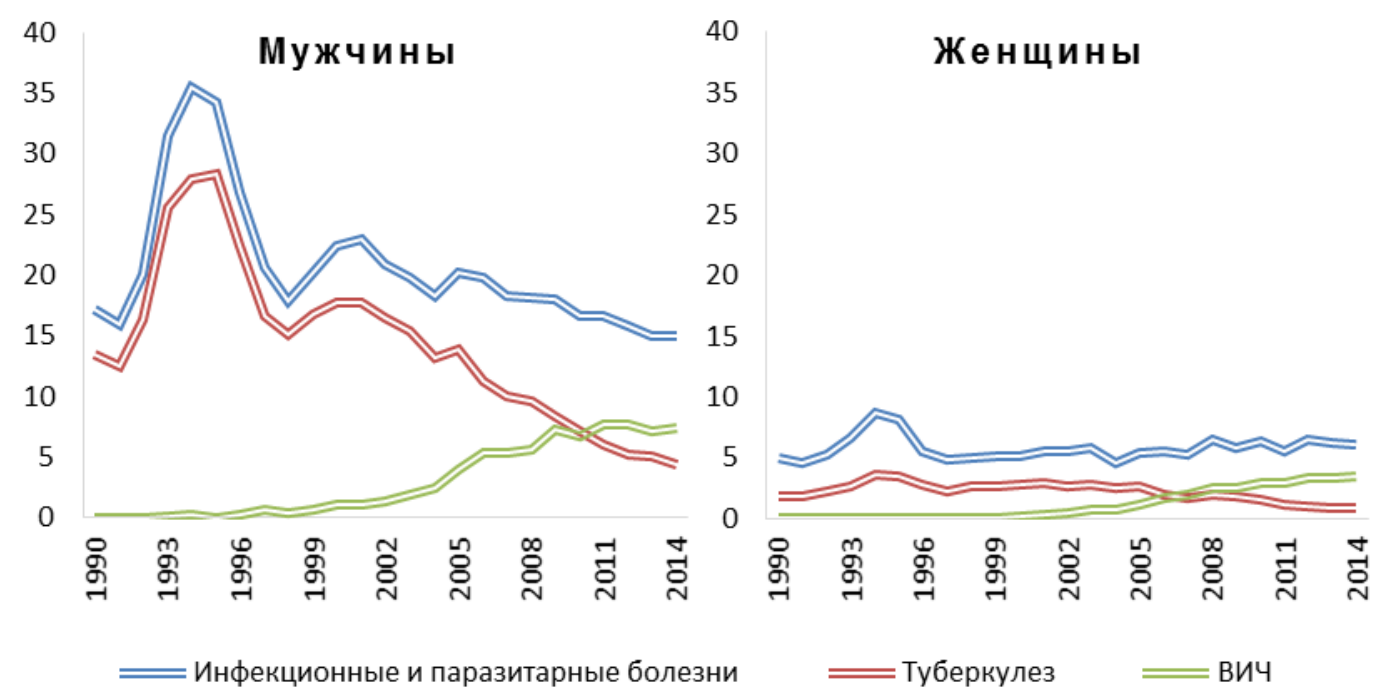

\section{Рисунок 22. Стандартизованные коэффициенты смертности от инфекционных и паразитарных болезней, туберкулеза и ВИЧ в Москве, 1990-2014, на 100000}

У мужчин до начала 2000-х годов основной вклад (в 1990 г. - 79\%) в смертность в этом классе вносил туберкулез. Затем смертность от туберкулеза стала снижаться, а вместе с тем снижался и его вклад - в 2014 г. он составил 29\%. У женщин доля туберкулеза была изначально меньшей (37\% в 1990 г.), но снижение вклада также было существенным (до $14 \%$ в 2014 г.).

Смерти от болезни, вызванной вирусом иммунодефицита человека (ВИЧ), регистрируются в Москве с начала 1990-х годов. Уровень СКС на 100000 был превышен у мужчин в 2000 г., а у женщин - в 2005 г. В 2014 г. уровень смертности от этой причины в Москве составил 7,4 на 100000 у мужчин и 3,4 у женщин против 11,3 и 4,9 в России в целом у мужчин и женщин соответственно. При этом эксперты говорят о наличии проблем с учетом заболеваемости и смертности от ВИЧ-инфекции [Покровский 2004]. Быстрый рост смертности от ВИЧ и снижение смертности от туберкулеза привели к тому, что в 2011 г. у мужчин и в 2007 г. у женщин смертность от ВИЧ превысила смертность от туберкулеза. Сейчас именно ВИЧ вносит основной вклад в смертность от инфекционных и паразитарных болезней (в 2014 г. 50\% у мужчин и 56\% у женщин).

Самый высокий уровень смертности от инфекционных и паразитарных болезней среди рассматриваемых мегаполисов наблюдается в Санкт-Петербурге, самый низкий - в Сингапуре (рисунок 23).

Как и в Москве, в Санкт-Петербурге, Сингапуре и Гонконге в 1990 г. смертность от туберкулеза вносила значительный вклад в смертность от всех инфекционных и паразитарных заболеваний. К 2013 г. во всех мегаполисах вклад этой причины смерти и уровень смертности от нее находились на низком уровне. Что же касается смертности от ВИЧ, то наиболее высокий уровень отмечался в Нью-Йорке в 1997 г. (50 и 18 на 100000 у мужчин и женщин соответственно). В других мегаполисах смертность была намного ниже. 
К 2013 г. смертность от ВИЧ-инфекции наибольшая из нероссийских мегаполисов была также в Нью-Йорке (9,6 и 4,0 на 100000), что выше, чем в Москве. Но в Нью-Йорке, в отличие от Москвы, уровень смертности от ВИЧ постоянно снижается. Вызывает беспокойство и ситуация в Санкт-Петербурге, где за 14 лет уровень смертности от ВИЧ вырос до 14,7 на 100000 у мужчин и до 5,4 на 100000 у женщин.

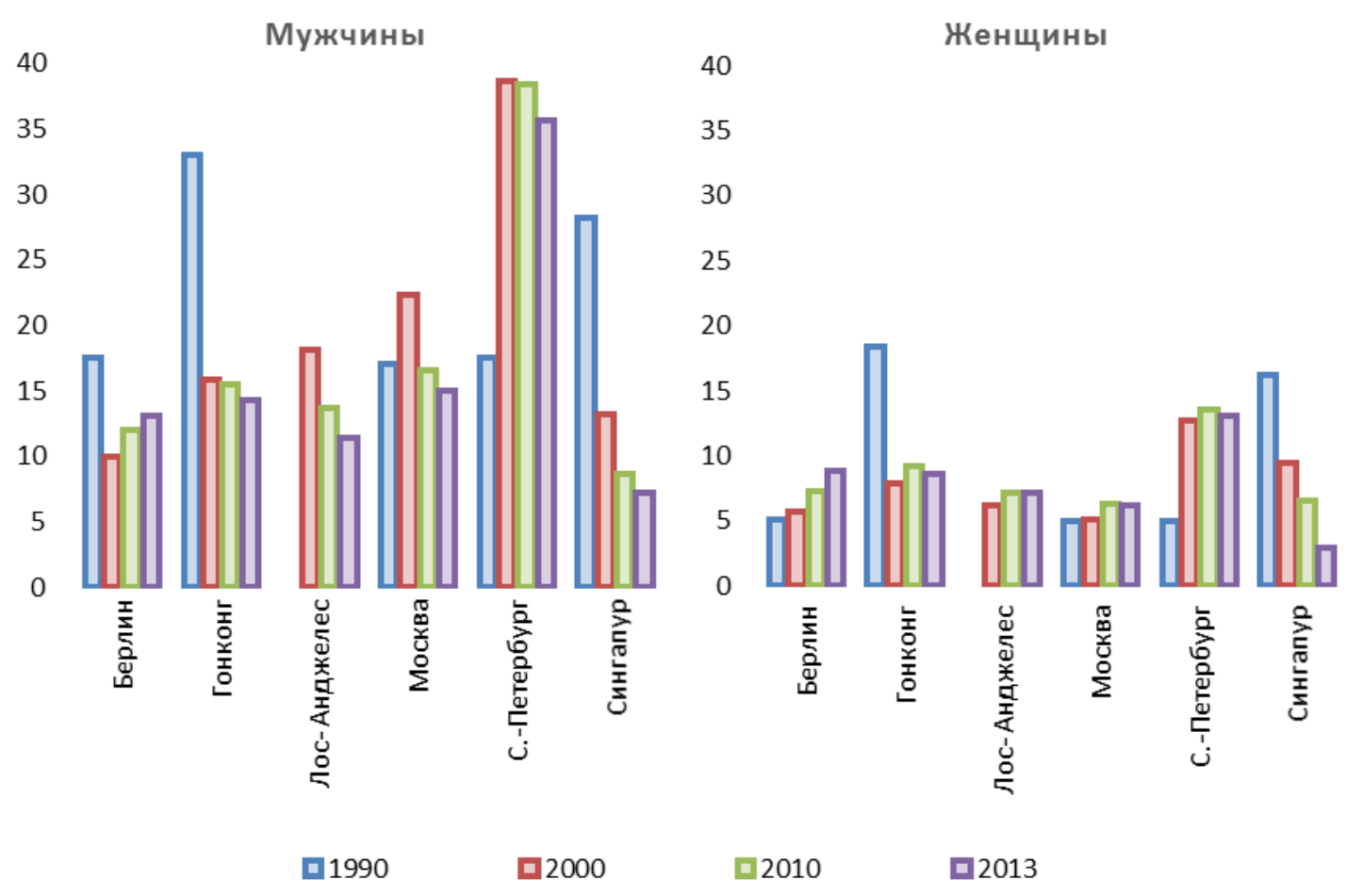

\section{Рисунок 23. Стандартизованные коэффициенты смертности от инфекционных и паразитарных болезней в 6 мегаполисах, 1990, 2000, 2010, 2013, на 100000}

Примечание: Лос-Анджелес - 2012 г.

\section{Сахарный диабет}

Еще одна причина, на которую обращают особое внимание в развитых странах, - сахарный диабет. Особое внимание уделяется этой причине в США из-за сильного роста числа людей с выявленным диагнозом "диабет" и смертности от этой причины. В Москве смертность от сахарного диабета снижалась в течение почти двух десятилетий (рисунок 24). Но в последние три года у мужчин (и два последние года у женщин) статистика фиксирует рост показателей смертности от этой болезни. До 2011 г. уровень смертности от этой причины был выше у женщин, но с 2012 г. мужчины вышли в "лидеры". Более высокая смертность от сахарного диабета у женщин - не особенность Москвы. Такое отмечается и в других мегаполисах (рисунок 25). После 2011 г. смертность от сахарного диабета (все формы) в Москве немного увеличилась - СКС у мужчин вырос в 1,3, а у женщин - в 1,1 раза. По России в целом наблюдается более, чем двукратный рост СКС от сахарного диабета.

Уровень смертности от сахарного диабета в зарубежных мегаполисах намного выше, и на долю умерших от этой причины в некоторых из них приходится до 4\% от всех умерших (Лос-Анджелес, Нью-Йорк). 


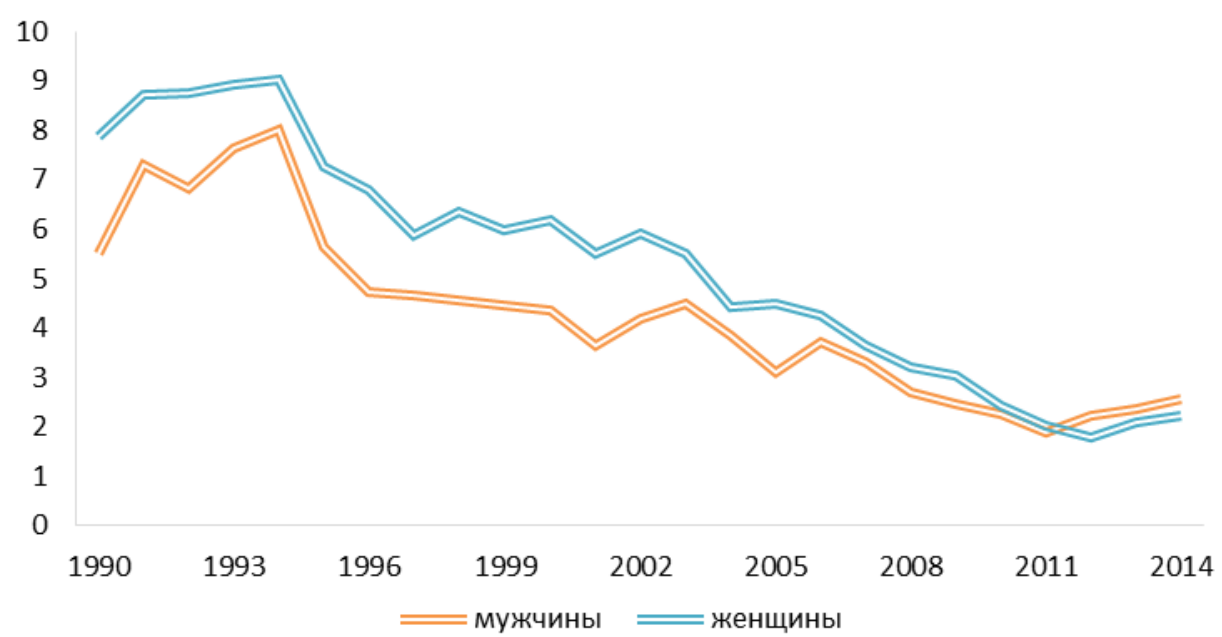

Рисунок 24. Стандартизованные коэффициенты смертности от сахарного диабета в Москве, 1990-2014, на 100000

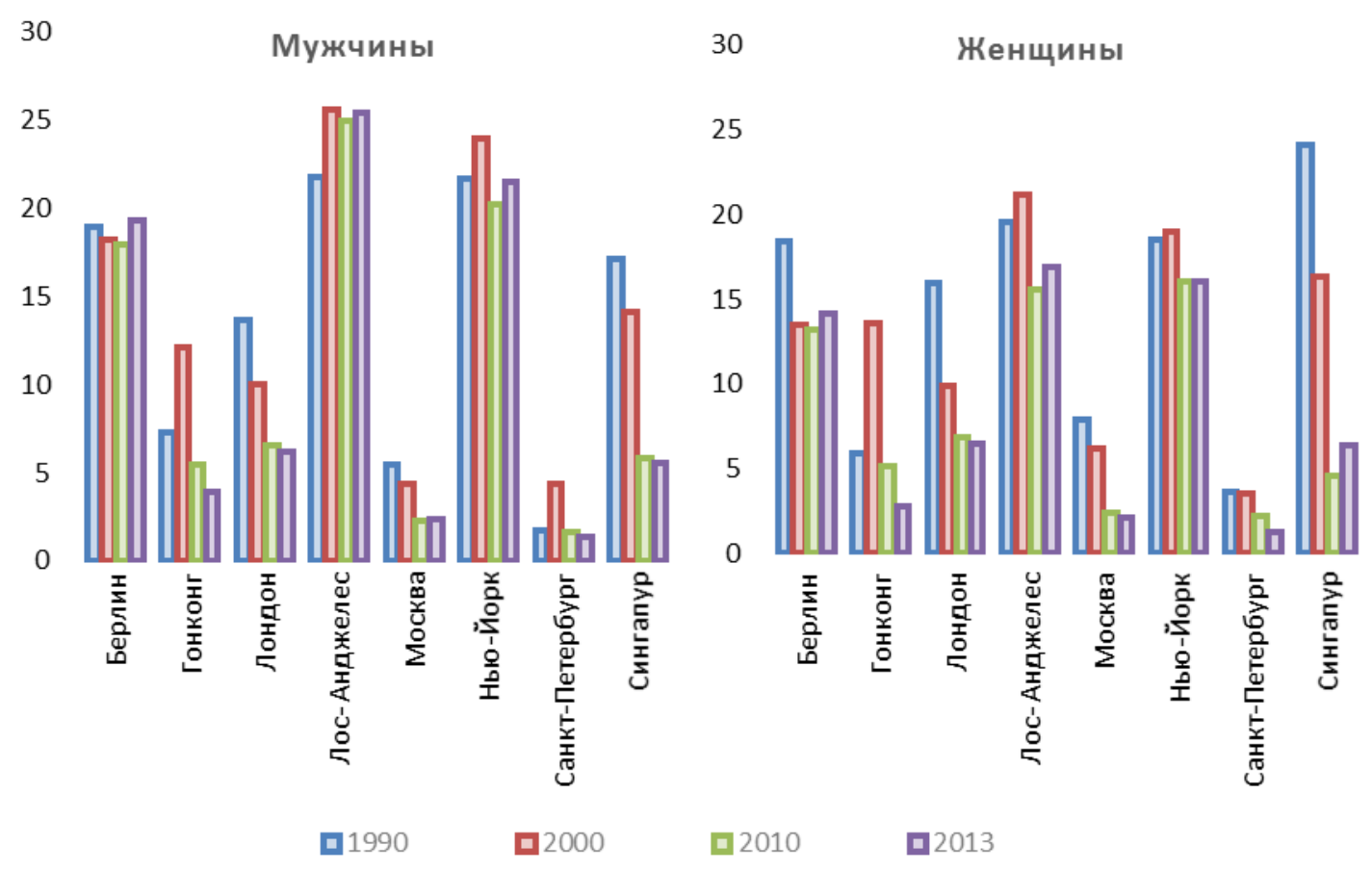

Рисунок 25. Стандартизованные коэффициенты смертности от сахарного диабета в 8 мегаполисах, 1990, 2000, 2010, 2013, на 100000

Примечание: Нью-Йорк- 1997 г.; Лос-Анджелес - 2012 г.

Большая часть из умерших от сахарного диабета приходится на лиц пожилого возраста. У людей в этом возрасте, как правило, есть не одна болезнь. Как и в случае пневмонии, выбор основной причины смерти зависит от практики, сложившейся в стране и регионе. 


\section{ПРИЧИНЫ ПЕРИНАТАЛЬНОЙ СМЕРТНОСТИ И ВРОЖДЕННЫЕ}

\section{АНОМАЛИИ}

От этой группы причин смерти в подавляющем большинстве умирают дети в возрасте до 1 года, хотя врожденные аномалии могут вызвать смерть и детей старше 1 года, и даже людей в пожилом возрасте. Но основная доля умерших приходится на младенческий период жизни. Доля и уровень смертности от этой группы причин служит косвенной характеристикой благополучия в области здоровья матери и ребенка, а также доступности и качества медицинских услуг для них. В Москве уровень смертности от этих причин самый высокий из всех рассматриваемых мегаполисов, хотя в 1990 г. первенство принадлежало Санкт-Петербургу (рисунок 26). Но уже в середине 1990-х годов в Санкт-Петербурге удалось снизить этот вид смертности. Сейчас уровень смертности от причин перинатальной смерти и врожденных аномалий в Санкт-Петербурге сопоставим по уровню с мегаполисами США, а по уровню младенческой смертности Санкт-Петербург уже много лет является регионом с минимальным показателем.

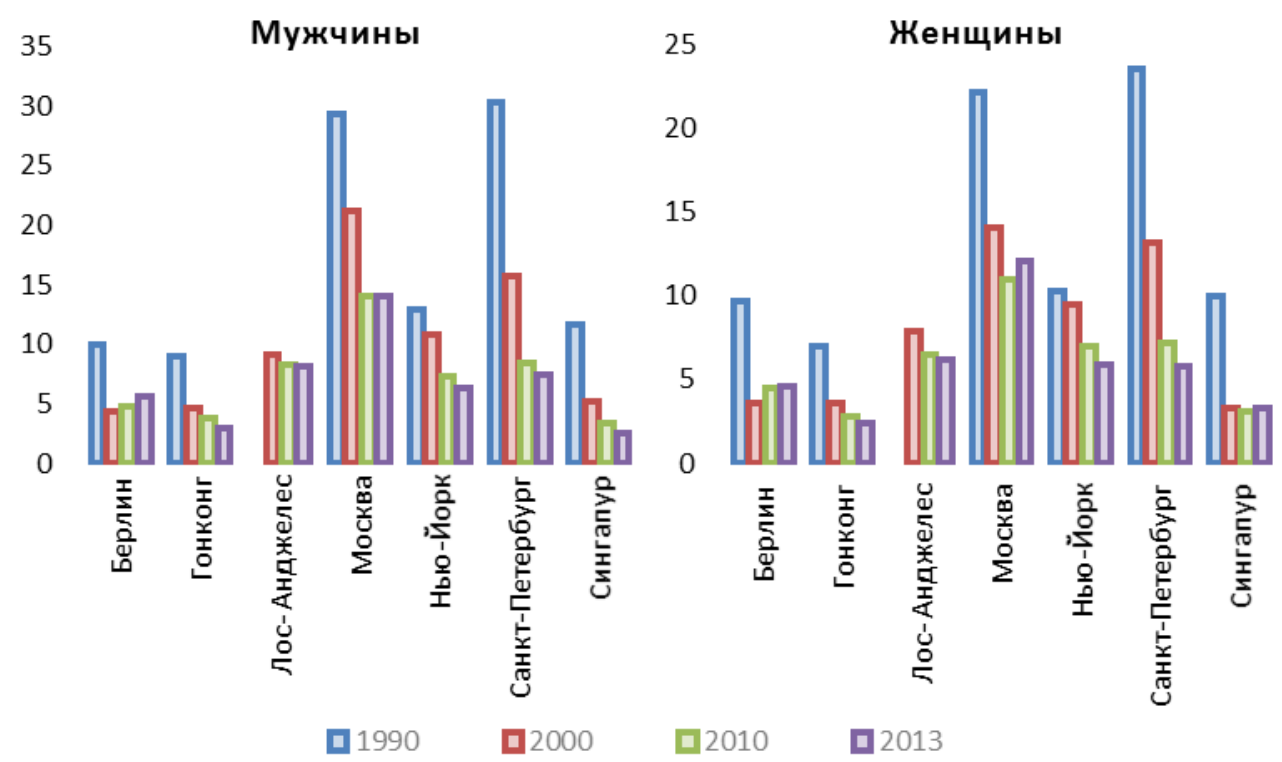

Рисунок 26. Стандартизованные коэффициенты смертности от причин перинатальной смертности и врожденных аномалий в 7 мегаполисах, 1990, 2000, 2010, 2013, на 100000

Примечание: Нью-Йорк- 1997 г.; Лос-Анджелес - 2012 г.

\section{Выводы}

В целом за последние четверть века - с 1990 г. по 2014 г. - стандартизованный коэффициент смертности от всех причин в Москве снизился у мужчин на $44 \%$ и у женщин на $42 \%$ (за 1990-2013 гг. - на 43 и 41\% соответственно). Темпы снижения показателя были выше, чем во многих зарубежных мегаполисах, как в целом, так и от некоторых важнейших классов причин смерти (таблица 13), что во многом объясняется более высоким начальным уровнем смертности. 
Таблица 13. Снижение стандартизованных коэффициентов смертности от важнейших классов причин смерти в 7 мегаполисах мира, 2013, в \% к 1990

\begin{tabular}{|c|c|c|c|c|}
\hline \multirow[b]{2}{*}{ Мегаполис } & \multirow[b]{2}{*}{ Все причины } & \multicolumn{3}{|c|}{ В том числе } \\
\hline & & $\begin{array}{l}\text { болезни системы } \\
\text { кровообращения }\end{array}$ & новообразования & $\begin{array}{l}\text { внешние } \\
\text { причины }\end{array}$ \\
\hline \multicolumn{5}{|c|}{ Мужчины } \\
\hline Берлин & 59,1 & 40,3 & 78,1 & 60,9 \\
\hline Гонконг & 61,4 & 49,0 & 68,2 & 69,5 \\
\hline Лондон & 58,8 & 39,3 & 56,9 & 92,9 \\
\hline Москва & 57,0 & 50,8 & 52,7 & 47,1 \\
\hline Санкт-Петербург & 72,1 & 70,1 & 66,9 & 66,1 \\
\hline Сингапур & 55,7 & 45,4 & 69,3 & 48,9 \\
\hline Токио & 68,6 & 46,4 & 78,9 & 54,0 \\
\hline \multicolumn{5}{|c|}{ Женщины } \\
\hline Берлин & 61,8 & 43,2 & 79,3 & 52,9 \\
\hline Гонконг & 55,3 & 37,5 & 75,1 & 58,4 \\
\hline Лондон & 69,1 & 47,7 & 74,8 & 98,9 \\
\hline Москва & 58,6 & 52,2 & 68,8 & 43,0 \\
\hline Санкт-Петербург & 69,6 & 65,4 & 79,3 & 59,3 \\
\hline Сингапур & 52,4 & 37,4 & 73,9 & 32,8 \\
\hline Токио & 69,2 & 38,6 & 80,6 & 61,1 \\
\hline
\end{tabular}

Однако ситуация в Москве в первой половине 1990-х годов была очень неблагоприятной, так что, несмотря на относительно высокие темпы снижения, отставание от других рассмотренных в этом разделе мегаполисов мира сохранилось, наметилось только его небольшое снижение. Как было показано (таблица 2), СКС от всех причин в Москве в 2013 г. был заметно выше, чем во всех взятых для сравнения зарубежных мегаполисах. Более того, у мужчин он был выше, чем в этих мегаполисах в 2000 г. и даже чем в некоторых из них в 1990 г., что дает основание говорить о двадцатилетнем отставании Москвы. У женщин результаты таких сопоставлений лишь немногим лучше.

Крайне невыгодно для Москвы сравнение с зарубежными мегаполисами по уровню смертности от болезней системы кровообращения (таблица 3). Здесь не только нынешний разрыв очень велик, но Москва по уровню смертности еще не приблизилась даже к уровню, наблюдавшемуся в зарубежных мегаполисах в 1990 г., особенно это касается мужчин. Нынешнюю Москву превосходит по смертности от болезней системы кровообращения только Берлин 1990 г., но тогда там еще сохранялись последствия социалистического образа жизни. Различия между восточной и западной частями Германии в уровне смертности ликвидировали практически полностью лишь к концу1990-х годов.

Различия в стандартизованных коэффициентах смертности от новообразований между Москвой и Санкт-Петербургом, с одной стороны, и зарубежными мегаполисами, с другой, не столь велики (таблица 4), но повсеместно не в пользу Москвы. Однако разрыв в демографических потерях Москвы и зарубежных мегаполисов за счет более высокой смертности от новообразований не достигает таких масштабов, как в случае сердечнососудистых заболеваний и внешних причин смерти.

Ситуация с внешними причинами смерти во многом повторяет ситуацию с болезнями системы кровообращения. В Москве смертность от внешних причин затрагивает более молодую, чем в зарубежных мегаполисах, часть населения, в силу чего ее неблагоприятное влияние на ожидаемую продолжительность жизни особенно велико. Хотя 
снижение смертности от этой, в значительной части предотвратимой, причины в Москве после 2000 г. было весьма значительным, но на фоне зарубежных мегаполисов достижения нашей столицы в снижении этого вида смертности кажутся несущественными. У мужчин, а иногда и у женщин, она в разы выше, чем в Лондоне, Нью-Йорке, Токио или Берлине (рисунок 14).

Уровень жизни, доступность качественной медицинской помощи в Москве выше, чем в соседних областях, а население Москвы имеет существенно более высокий уровень образования. Поэтому не удивительно, что Москва заметно отличается от ближайших регионов России по уровню смертности от болезней системы кровообращения или внешних причин. Но более низкая смертность от новообразований, которая довольно стабильна во времени и мало различается между регионами страны, побуждает искать возможные объяснения относительно низкого уровня смертности населения столицы также и в особенностях ее статистики [Андреев, Кваша, Харькова 2006]. Однако даже если посчитать московскую статистику смертности достоверной, на фоне зарубежных мегаполисов успехи Москвы выглядят достаточно скромно. Если говорить о сходствах и различиях смертности в Москве и зарубежных мегаполисах, то приходится признать, что различий пока больше, чем сходства.

Тем не менее успехи Москвы в снижении смертности в 2000-2014 гг. все же внушают некоторый оптимизм, а цель приближения уровня смертности в городе к уровням зарубежных мегаполисов не выглядит недостижимой. Трудно только предугадать, как будут развиваться события в условиях ухудшающейся экономической ситуации. Полезно напомнить, что в годы кризиса первой половины 1990-х годов Москва полностью утратила все ранее существовавшие преимущества перед соседними регионами в уровне смертности.

\section{ЛИТЕРАТУРА}

Аксель Е.М. (2009). Статистика злокачественных новообразований женских половых органов // Опухоли женской репродуктивной системы. 1-2: 76-80.

Аксель Е.М. (2012). Статистика злокачественных новообразований женской половой сферы. // Онкогинекология. 1:18-23.

Андреев Е.М. (2002). Возможные причины колебаний продолжительности жизни в России в 90-ые годы // Вопросы статистики. 11: 3-15.

Андреев Е.М. (2016). Правильно ли считают умерших от случайных отравлений алкоголем? // Демоскоп Weekly. № 673 - 674. URL:

http://demoscope.ru/weekly/2016/0673/tema01.php (дата обращения: 26.02.2016).

Андреев Е.М., Е.А. Кваша, Т.Л. Харькова (2006). Особые точки на карте смертности // Население России 2003-2004. Одиннадцатый-двенадцатый ежегодный демографический доклад / Отв. ред. А.Г. Вишневский. М.: 298-305.

Андреев Е.М., Е.А. Кваша, Т.Л. Харькова (2013). Смертность и продолжительность жизни // Население России 2010-2011. Восемнадцатый-девятнадцатый ежегодный демографический доклад / Отв. ред. А.Г. Вишневский. М.: Изд. дом Высшей школы экономики: 385-443. 
Андреев Е.М., Е.А. Кваша, Т.Л. Харькова, С.А. Тимонин (2015). Смертность и продолжительность жизни // Население России 2013. Двадцать первый ежегодный демографический доклад / Отв. Ред. С.В. Захаров. М.: Изд. дом Высшей школы экономики: 182-273.

Васин С.А. (2015). Смертность от повреждений с неопределенными намерениями в России и в других странах // Демографическое обозрение. 1:92. URL: http://demreview.hse.ru/data/2015/10/22/1079399391/DemRev_2_1_2015_89-124.pdf (дата обращения: 26.02.2016).

ВО3 (2015). Вирус папилломы человека (ВПЧ) и рак шейки матки // Информационный бюллетень №380. URL: http://www.who.int/mediacentre/factsheets/fs380/ru/ (дата обращения: 26.02.2016).

Данилова И.А. (2015). Особенности построения непрерывных рядов показателей смертности по причинам смерти в России // Вопросы статистики. 11: 58-68.

Демографическая модернизация России, 1900-2000 (2006) / Под ред. А.Г. Вишневского. М.: Новое издательство. 601 с.

Иванова А.Е., Т.П. Сабгайда, В.Г. Семенова, В.Г. Запороженко, Е.В. Землянова, С.Ю. Никитина (2013). Факторы искажения структуры причин смерти трудоспособного населения России // Социальные аспекты здоровья населения. 4(32). URL: http://vestnik.mednet.ru/content/view/491/30/lang,ru/ (дата обращения: 26.02.2016).

Мерабишвили В.М. (2013). Аналитическая эпидемиология рака желудка // Вопросы онкологии. 59(5): 565.

Мерабишвили В.М., Н.Г. Петрова, А.В. Атрощенко, М.В. Харитонов (2014). Анализ заболеваемости и смертности мужского населения от рака предстательной железы (популяционное исследование) // Креативная онкология и хирургия. Электронный научно-практический журнал. 2. URL: http://eoncosurg.com/analiz-zabolevaemosti-ismertnosti-muzhskogo-naseleniya-ot-raka-predstatelnoj-zhelezy-populyatsionnoeissledovanie (дата обращения: 26.02.2016).

Оганов Р.Г., В.В. Константинов, Т.Н. Тимофеева, А.В. Капустина, А.Д. Деев, С.А. Шальнова, И.Е. Колтунов, Ю.А. Баланова, И.Н. Лельчук (2011). Эпидемиология артериальной гипертонии в России. Результаты федерального мониторинга 2003-2010 гг. // Кардиоваскулярная терапия и профилактика. 1: 9-13.

Покровский В.В. (2004). Социально значимые инфекции в XXI веке // Народонаселение. 3: 93-96.

Ревич Б.А., М. Подольная, Е.М. Аксель, Т.Л. Харькова, Е.А. Кваша (2014). Особенности онкологической заболеваемости и смертности трудоспособного населения Москвы // Профилактическая медицина. 17 (5): 31.

Семенова В.Г., О.И. Антонова (2007). Достоверность статистики смертности (на примере смертности от травм и отравлений в Москве) // Социальные аспекты здоровья населения (Электронный научный журнал). 2(7). URL: http://vestnik.mednet.ru/content/view/28/30/ (дата обращения: 26.02.2016).

Состояние онкологической помощи населению России в 2014 году (2015) / Под ред. А.Д. Каприна, В.В. Старинского, Г.В. Петровой. М.: МНИОИ им. П.А. Герцена.

Фаттахов Т.А. (2015). Дорожно-транспортные происшествия и смертность в России: 19562012 // Демографическое обозрение. 2: 6-36. URL: https://demreview.hse.ru/2015-2/167976833.html (дата обращения: 26.02.2016). 
Школьников В.М., Е.М. Андреев, М. Макки, Д.А. Леон (2014). Рост продолжительности жизни в России 2000-х годов // Демографическое обозрение. 1(2): 5-37. URL: https://demreview.hse.ru/data/2014/11/20/1101110530/DemRev_1_2_2014_5-37.pdf (дата обращения: 26.02.2016).

Andreev E.M., V.M. Shkolnikov, W.A. Pridemore, S.Yu. Nikitina (2015). A method for reclassifying cause of death in cases categorized as "event of undetermined intent" // Population Health Metrics. 13, Art. 23. DOI:10.1186/s12963-015-0048-y.

Shaposhnikov D., B. Revich, T. Bellander, G.B. Bedada, M. Bottai, T.L. Kharkova, E.A. Kvasha, E. Lezina, T. Lind, E. Semutnikova, G. Pershagen (2014). Mortality related to air pollution with the Moscow heat wave and wildfire of 2010 // Epidemiology. 25 (3): 359-364.

Shkolnikov V., M. McKee., D.A. Leon (2001). Changes in life expectancy in Russia in the mid1990s // The Lancet. 357(9260): 917-921. doi:10.1016/S0140-6736(00)04212-4.

UN (2015). World urbanization prospects: The 2014 revision. New York: United Nations.

Waterhouse J., C.S. Muir, P. Correa, J. Powell, eds. (1976). Cancer incidence in five continents. Lyon: IARC. 3: 456.

WHO (2014). Comprehensive cervical cancer control. A guide to essential practice. Second edition.

Wroblewski L.E., R.M. Peek, Jr. Wilson, K.T. Wilson (2010). Helicobacter pylori and gastric cancer: factors. That modulate disease risk // Clinical microbiology reviews. 23 (4): 713-739. 


\title{
MORTALITY IN MOSCOW AND OTHER MEGACITIES OF THE WORLD: SIMILARITIES AND DIFFERENCES
}

\author{
EVGENY ANDREEV, EKATERINA KVASHA, TATIANA KHARKOVA
}

\begin{abstract}
The paper is devoted to a comparison of mortality by cause of death in Moscow and other megacities of the world in the period after 1990. The selection of megacities was determined by the availability of detailed mortality data in the period under consideration. The objects of our comparison are data for Berlin, Hong Kong, London, Los Angeles, New York, Singapore, St. Petersburg, and Tokyo. Mortality from major groups of causes of death are considered, including cardiovascular diseases, neoplasms, external causes, diseases of the respiratory and digestive organs, infections and some others. The analysis uses standardized mortality rates by cause of death.

The mortality level in Moscow is significantly lower than in the majority of regions of Russia, but is still substantially higher than in foreign megacities. Due to a big lag at the beginning of the period, the mortality level in Moscow nowadays is higher than in all considered foreign megalopolises in the year 2000. Where Moscow's mortality level most lags behind others is in mortality from circulatory diseases and external causes. Moscow's successes in reducing mortality in 2000-2014 are very impressive. However, it is difficult to predict how events will unfold in the deteriorating economic situation.
\end{abstract}

Key words: Moscow, mortality, causes of death, megacities, circulatory diseases, external causes, neoplasms.

\footnotetext{
Evgeny M. ANDREev, NeW Economic School, RusSia.

Ekaterina A. Kvasha, National Research University Higher School of Economics, Russia.

TAtiana L. Kharkova (tkharkova@hse.ru), NATIONAL RESEARCH University Higher SCHOOL OF EcONOMICS,

RUSSIA.
}

THE RESULTS OF THE PROJECT "DEMOGRAPHIC DEVELOPMENT IN RUSSIA IN 2005-2015 IN THE CONTEXT OF LONG-TERM TRENDS", CARRIED OUT WITHIN THE FRAMEWORK OF THE BASIC RESEARCH PROGRAM AT THE NATIONAL RESEARCH UNIVERSITY HIGHER SCHOOL OF ECONOMICS (HSE) IN 2016, ARE PRESENTED IN THIS PAPER.

DATE RECEIVED: JULY 2016.

\section{REFERENCES}

Aksel E.M. (2009). Statistika zlokachestvennykh novoobrazovaniy zhenskikh polovykh organov [Statistics of malignant tumors of female genitals] // Opukholi zhenskoy reproduktivnoy sistemy [Women reproductive system tumors]. 1-2: 76-80.

Aksel E.M. (2012). Statistika zlokachestvennykh novoobrazovaniy zhenskoy polovoy sfery [Statistics of malignant neoplasms of female genital sphere] // Onkoginekologiya [Gynecologic Oncology]. 1:18-23.

Andreev E.M. (2002). Vozmozhnye prichiny kolebaniy prodolzhitel'nosti zhizni v Rossii v 90-ye gody [Possible reasons of fluctuations in life expectancy in Russia in the 1990s] // Voprosy statistiki [Problems in statistics]. 11: 3-15.

Andreev E.M. (2016). Pravil'no li schitayut umershikh ot sluchaynykh otravleniy alkogolem? [Is number of deaths from accidental alcohol poisoning counted correctly?] // Demoskop Weekly. №673-674. URL: http://demoscope.ru/weekly/2016/0673/tema01.php (accessed: 26.02.2016).

Andreev E.M., E.A. Kvasha, T.L. Kharkova (2006). Osobye tochki na karte smertnosti [The special points on the map of mortality] // Naselenie Rossii 2003-2004. Odinnadtsatyy- 
dvenadtsatyy ezhegodnyy demograficheskiy doklad [The population of Russia 2003-2004. Eleventh-twelfth annual demographic report] / A.G. Vishnevsky, ed. Moscow: 298-305.

Andreev E.M., E.A. Kvasha, T.L. Kharkova (2013). Smertnost' i prodolzhitel'nost' zhizni [Mortality and life expectancy] // Naselenie Rossii 2010-2011. Vosemnadtsatyydevyatnadtsatyy ezhegodnyy demograficheskiy doklad [Population of Russia 2010-2011. Eighteenth-nineteenth annual demographic report] / A.G. Vishnevsky, ed. Moscow: Izd. dom Vysshey shkoly ekonomiki: 385-443.

Andreev E.M., E.A. Kvasha, T.L. Kharkova, S.A. Timonin (2015). Smertnost' i prodolzhitel'nost' zhizni [Mortality and life expectancy] // Naselenie Rossii 2013. Dvadtsat' pervyy ezhegodnyy demograficheskiy doklad [Population of Russia of 2013. The twenty-first annual demographic report] / S.V. Zakharov, ed. Moscow: Izd. dom Vysshey shkoly ekonomiki: $182-273$.

Andreev E.M., V.M. Shkolnikov, W.A. Pridemore, S.Yu. Nikitina (2015). A method for reclassifying cause of death in cases categorized as "event of undetermined intent" // Population health metrics. 13, Art. 23. DOI:10.1186/s12963-015-0048-y.

Danilova I.A. (2015). Osobennosti postroeniya nepreryvnykh ryadov pokazateley smertnosti po prichinam smerti v Rossii [Features of the construction of a continuous series of mortality by causes of death in Russia] // Voprosy statistiki [Problems in statistics]. 11: 58-68.

Demograficheskaya modernizatsiya Rossii: 1900-2000 [Demographic modernization of Russia: 1900-2000] (2006) / A.G. Vishnevsky, ed. Moscow: Novoe izdatel'stvo.

Fattakhov T.A. (2015). Dorozhno-transportnye proisshestviya i smertnost' v Rossii: 1956-2012 [Road traffic accidents and mortality in Russia: 1956-2012] // Demograficheskoe obozrenie [Demographic review]. 2: 6-36 (accessed: 26.02.2016).

Ivanova A.E., T.P. Sabgaida, V.G. Semenova, V.G. Zaporozhenko, E.V. Zemlianova, S.Iu. Nikitina (2013). Faktory iskazheniya struktury prichin smerti trudosposobnogo naseleniya Rossi [Factors distorting structure of causes of death of working-age population of Russia] // Sotsial'nye aspekty zdorov'ya naseleniyai [Social aspects of population health]. 4(32) URL: http://vestnik.mednet.ru/content/view/491/30/lang,ru/ (accessed: 26.02.2016).

Merabishvili V.M. (2013). Analiticheskaya epidemiologiya raka zheludka [Analytical epidemiology of gastric cancer] // Voprosy onkologii [Problems in oncology]. 59(5): 565.

Merabishvili V.M., N.G. Petrova, A.V. Atrochshenko, M.V. Kharitonov (2014). Analiz zabolevaemosti i smertnosti muzhskogo naseleniya ot raka predstatel'noy zhelezy (populyatsionnoe issledovanie) [Analysis of incidence of and mortality from prostate cancer in male population (population study)] // Kreativnaya onkologiya i khirurgiya. Elektronnyy nauchno-prakticheskiy zhurnal [Creative oncology and surgery]. 2. URL: http://eoncosurg.com/analiz-zabolevaemosti-i-smertnosti-muzhskogo-naseleniya-ot-rakapredstatelnoj-zhelezy-populyatsionnoe-issledovanie (accessed: 26.02.2016).

Oganov R.G., V.V. Konstantinov, T.N. Timofeeva, A.V. Kapustina, A.D. Deev, S.A. Shal'nova, I.E. Koltunov, Iu.A. Balanova, I.N. Lel'chuk (2011). Epidemiologiya arterial'noy gipertonii v Rossii. Rezul'taty federal'nogo monitoringa 2003-2010 gg. [Epidemiology of arterial hypertension in Russia. the federal monitoring results of 2003-2010] // Kardiovaskulyarnaya terapiya i profilaktika [Cardiovascular therapy and prevention]. 1: 9-13.

Pokrovsky V.V. (2004). Sotsial'no znachimye infektsii v XXI veke [Socially important infections in the XXI century] // Narodonaselenie [Population]. 3: 93-96.

Revich B. A., M. Podolnaia, E. Aksel, T. L. Kharkova, E. A. Kvasha (2014). Osobennosti onkologicheskoy zabolevaemosti i smertnosti trudosposobnogo naseleniya Moskvy [Features 
of cancer incidence and mortality in the working age population of Moscow] // Profilakticheskaya meditsina [Preventive medicine]. 7 (5): 31.

Semenova V.G., O.I. Antonova (2007). Dostovernost' statistiki smertnosti (na primere smertnosti ot travm i otravleniy v Moskve) [The validity of the mortality statistics (on example of mortality from injury and poisoning in Moscow)] // Sotsial'nye aspekty zdorov'ya naseleniya. Elektronnyy nauchnyy zhurnal [Social aspects of population health]. 2(7). URL: http://vestnik.mednet.ru/content/view/28/30/ (accessed: 26.02.2016).

Shaposhnikov D., B. Revich, T. Bellander, G.B. Bedada, M. Bottai, T.L. Kharkova, E.A. Kvasha, E. Lezina, T. Lind, E. Semutnikova, G. Pershagen (2014). mortality related to air pollution with the Moscow heat wave and wildfire of 2010 // Epidemiology. 25 (3): 359-364.

Shkolnikov V., M. McKee., D.A. Leon (2001). Changes in life expectancy in Russia in the mid1990s // The Lancet. 357(9260): 917-921. doi:10.1016/S0140-6736(00)04212-4.

Shkolnikov V.M., E.M. Andreev, M. McKee, D.A. Leon (2014). Rost prodolzhitel'nosti zhizni v Rossii 2000-kh godov [The growth in life expectancy in Russia at the 2000s] // Demograficheskoe obozrenie [Demographic review]. 1(2): 5-37. URL: https://demreview.hse.ru/data/2014/11/20/1101110530/DemRev_1_2_2014_5-37.pdf (accessed: 26.02.2016).

Sostoyanie onkologicheskoy pomoshchi naseleniyu Rossii v 2014 godu [State oncological assistance to the population of Russia in 2014] (2015) / A.D. Kaprin, V.V. Starinskii, G.V. Petrova, eds. Moscow: MNIOI im. P.A. Gertsena.

UN (2015). World urbanization prospects: The 2014 revision. New York: United Nations.

Vasin S.A. (2015). Smertnost' ot povrezhdeniy s neopredelennymi namereniyami v Rossii i v drugikh stranakh [Deaths from injury with uncertain intentions in Russia and in other countries] // Demograficheskoe obozrenie [Demographic review]. 1:92. URL: http://demreview.hse.ru/data/2015/10/22/1079399391/DemRev_2_1_2015_89-124.pdf (accessed: 26.02.2016).

VOZ (2015). Virus papillomy cheloveka (VPCh) i rak sheyki matki [Human papillomavirus (HPV) and cervical cancer] // Informatsionnyy byulleten' [Bulletin of the World Health Organization].380. URL: http://www.who.int/mediacentre/factsheets/fs380/ru/ (accessed: 26.02.2016).

Waterhouse J., C.S. Muir, P. Correa, J. Powell, eds. (1976). Cancer incidence in five continents. Lyon: IARC. 3: 456.

WHO (2014). Comprehensive cervical cancer control. A guide to essential practice. Second edition.

Wroblewski L.E., R.M. Peek, Jr. Wilson, K.T. Wilson (2010). Helicobacter pylori and gastric cancer: factors. that modulate disease risk // Clinical microbiology reviews. 23 (4): 713-739. 